Review

\title{
Nutrient Intake Values for Folate during Pregnancy and Lactation Vary Widely around the World
}

\author{
Rosemary A. Stamm and Lisa A. Houghton * \\ Department of Human Nutrition, University of Otago, Dunedin 9016, New Zealand; \\ E-Mail: rosemary.stamm@otago.ac.nz \\ * Author to whom correspondence should be addressed; E-Mail: lisa.houghton@otago.ac.nz; \\ Tel.: +64-3-479-7294; Fax: +64-3-479-7958.
}

Received: 25 July 2013; in revised form: 3 September 2013 / Accepted: 3 September 2013 / Published: 30 September 2013

\begin{abstract}
Folate is a B-vitamin with particular importance during reproduction due to its role in the synthesis and maintenance of DNA. Folate is well known for its role in preventing neural tube defects (NTDs) during the periconceptional period. There is also an increased need for folate throughout pregnancy to support optimal growth and development of the fetus and blood volume expansion and tissue growth of the mother. During lactation, women are at risk of folate deficiency due to increased demands to accommodate milk folate levels. Nutrient Intake Values (NIVs) for folate have been calculated to take into account additional needs during pregnancy and lactation. However, these values vary widely between countries. For example, the folate requirement that is set to meet the needs of almost all healthy women during pregnancy varies from $300 \mu \mathrm{g} / \mathrm{day}$ in the United Kingdom to $750 \mu \mathrm{g} /$ day in Mexico. Currently, there is no accepted standardized terminology or framework for establishing NIVs. This article reviews country-specific NIVs for folate during pregnancy and lactation and the basis for setting these reference values.
\end{abstract}

Keywords: folate requirements; Nutrient Intake Values; pregnancy; lactation

\section{Introduction}

Folate is a B-vitamin involved in one-carbon transfer reactions and plays a fundamental role in nucleotide biosynthesis and methylation reactions [1]. During pregnancy and lactation, the demand for folate is increased to support both the normal physiological changes of the mother and optimal 
growth and development of the fetus and offspring [2,3]. Observational studies in the 1960s demonstrated higher rates of folate-related anemia (megaloblastic anemia) in unsupplemented pregnant and lactating mothers [4-6]. As a result, a number of countries recommended supplementation of folic acid during the prenatal period [7]. Years later, one of the better-known consequences of low folate status emerged with scientific evidence supporting the use of periconceptional folic acid supplementation for the prevention of neural tube defects (NTDs) [8]. While other pregnancy complications have been associated with folate deficiency, data are limited and the findings unclear. More recently, studies have suggested improved neurodevelopment outcomes in children of mothers with higher blood folate concentrations or mothers receiving prenatal folic acid supplements [9-12]. Thus, establishing nutrient intake recommendations to optimize folate status for pregnant women remains challenging. Moreover, the dietary contributors to folate intake have evolved since the first nutrient recommendations for folate, with an increasing number of countries mandating folic acid fortification of their food supply [8]. Limitations in our understanding of folate bioavailability make accurate interpretation of dietary intakes difficult.

Despite the challenges, most countries have established recommended folate intakes for their populations; however, requirements among countries vary considerably due to a lack of a standardized framework for deriving these standards. In 2005, the United Nations University's Food and Nutrition Programme, in collaboration with the Food and Agriculture Organization (FAO), the World Health Organization (WHO) and UNICEF, assembled an international working group to establish a common approach for establishing nutrient intake recommendations. The umbrella term Nutrient Intake Values (NIVs) was proposed to refer to a set of specific nutrient standards and is synonymous with the U.S. and Canada Dietary Reference Intakes (DRIs) and the U.K. Dietary Reference Values (DRVs) among others $[13,14]$.

In this paper, we will briefly review the approach used for deriving folate requirements, including considerations of the indicators used to establish adequate intakes, folate bioavailability and the potential influence of gene polymorphisms on requirements. The next section will compare current folate reference values from over 50 countries and describe the scientific foundation of the NIVs for non-pregnant, non-lactating (NPNL), pregnant, and lactating women.

\section{Terminology}

The terms Average Nutrient Requirement (ANR), Individual Nutrient Level $\left(\mathrm{INL}_{\mathrm{x}}\right)$ and the Upper Nutrient Level (UNL) will be used throughout the article as they are aligned with proposed common terminology of the international working group [14]. Table 1 provides a list of comparable terminology currently used by different countries and organizations. The ANR is synonymous with the U.S. and the U.K. Estimated Average Intake (EAR) or the European Community Average Requirement (AR). The ANR is derived from a statistical distribution of requirements for a criterion, and is the value that should be used for assessing the adequacy of population intakes and planning of group diets [15]. The ANR also serves as a basis for determining the $\mathrm{INL}_{\mathrm{x}}$ - the recommended intake level for all healthy individuals in the population. An $\mathrm{INL}_{\mathrm{x}}$ set at 2 standard deviations above the ANR would be $\mathrm{INL}_{98}$, covering $98 \%$ of the population nutrient requirement. This value is equivalent to the U.S. Recommended Dietary Allowance (RDA), and U.K. Recommended Nutrient Intake (RNI) and the 
European Community Population Reference Intake (PRI). The $\mathrm{INL}_{\mathrm{x}}$ should not be used for assessing the adequacy of population intakes; rather it should be used for planning individual's intakes [15].

Table 1. Sources of country Nutrient Intake Values and country specific terminology used for folate Nutrient Intake Values.

\begin{tabular}{|c|c|c|c|c|c|c|c|}
\hline \multirow{3}{*}{ Country } & \multirow{3}{*}{ Year } & \multicolumn{4}{|c|}{ Equivalent Term Used for NIVs } & \multirow{3}{*}{ Adapted from } & \multirow{3}{*}{ Reference } \\
\hline & & \multicolumn{4}{|c|}{ for Folate } & & \\
\hline & & NIV & ANR & INL $_{98}$ & SI & & \\
\hline Australia and New Zealand & 2005 & NRV & EAR & RDI & - & U.S. & {$[16]$} \\
\hline Austria, Germany, and Switzerland & 2000 & $\dagger$ & - & $\dagger$ & - & Own (DACH) & [17] \\
\hline Belgium & 2009 & - & - & PRI & - & EC & {$[18]$} \\
\hline Brazil & 2000 & - & - & IDR & - & WHO & [19] \\
\hline Bulgaria & 2005 & - & - & $\dagger$ & - & U.S. & {$[20]$} \\
\hline Central America ${ }^{1}$ and Panama & 1994 & - & - & RDD & - & $\begin{array}{c}\text { WHO/FAO } \\
1988\end{array}$ & [21] \\
\hline China & 2010 & DRI & EAR & RNI & - & U.S. & {$[22]$} \\
\hline Colombia & 1988 & - & - & $\dagger$ & - & Own & [23] \\
\hline Croatia & 2004 & - & - & $\dagger$ & - & EC and U.S. & [24] \\
\hline Cuba & 2008 & - & - & DRI & - & U.S./WHO & [25] \\
\hline Denmark, Iceland and Sweden & 2004 & NNR & $\mathrm{AR}$ & RI & - & Own (NNR) & [26] \\
\hline Estonia & 2006 & - & - & $\dagger$ & - & NNR & [27] \\
\hline European Community & 1993 & RDA & AR & PRI & - & Own (EC) & [28] \\
\hline Finland & 2005 & NNR & $\mathrm{AR}$ & RI & - & NNR & [29] \\
\hline France & 2001 & - & - & - & ANC & Own & [30] \\
\hline Greece & 1993 & RDA & $\mathrm{AR}$ & PRI & - & EC & [31] \\
\hline Hungary & 2005 & - & - & - & $\dagger$ & EC and U.S. & {$[32]$} \\
\hline India & 2010 & - & - & RDA & - & Own & [33] \\
\hline Ireland & 1999 & - & - & RDA & - & Own & [34] \\
\hline Italy & 2012 & LARN & $\mathrm{AR}$ & PRI & - & U.S. & {$[35]$} \\
\hline Japan & 2005 & DRI & EAR & RDA & - & Own & {$[36]$} \\
\hline Latvia & 2008 & - & - & $\dagger$ & - & Own & [37] \\
\hline Lithuania & 1999 & RPN & - & $\mathrm{RP}$ & - & Own & [38] \\
\hline Mexico & 2004 & VNR & RNP & - & IDS & U.S. & [39] \\
\hline Norway & 2005 & NNR & AR & RI & - & NNR & [40] \\
\hline Poland & 2008 & - & EAR & $\mathrm{RDA}$ & - & U.S. & [41] \\
\hline Republic of Macedonia & 2001 & - & - & $\dagger$ & - & $\mathrm{EC}$ & {$[42]$} \\
\hline $\begin{array}{c}\text { Republica Srpska, Bosnia and } \\
\text { Herzegovina }\end{array}$ & 2004 & - & - & $\dagger$ & - & WHO/FAO & [43] \\
\hline Russian Federation & 2008 & - & - & $\dagger$ & - & U.S. & [44] \\
\hline Slovakia & 1997 & - & - & OVD & - & $\begin{array}{c}\text { Own and } \\
\text { WHO/FAO }\end{array}$ & {$[45]$} \\
\hline Slovenia & 2004 & - & - & PVD & - & DACH & [46] \\
\hline South Korea & 2010 & KDRI & EAR & RI & - & U.S. & [47] \\
\hline
\end{tabular}


Table 1. Cont.

\begin{tabular}{cccccccc}
\hline Southeast Asia Region $^{2}$ & 2005 & - & - & RDA & - & U.S. & {$[48]$} \\
Spain & 2010 & - & - & IDR & - & Own and & Ireland \\
The Netherlands & 2003 & DRI & EAR & RDA $^{3}$ & AI $^{4}$ & Own & {$[50]$} \\
United Kingdom & 1991 & DRV & EAR & RNI & - & Own & {$[51]$} \\
United States and Canada & 1998 & DRI & EAR & RDA & - & Own (U.S.) & {$[52]$} \\
WHO/FAO & 2004 & - & EAR & RNI & - & U.S. & {$[53]$} \\
\hline
\end{tabular}

AI: adequate intake; ANC: apports nutritionnels conseillés; ANR: average nutrient requirement; AR: average requirement; DACH: Germany, Austria, and Switzerland; DRI: dietary reference intake; DRV: dietary reference value; EAR: estimated average requirement; EC: European community; FAO: Food and Agriculture Organization; IDR: ingestión diaria recomendada (Brazil); IDR: ingestas dietéticas de referencia (Spain); IDS: ingestión diaria sugerida; INL: individual nutrient level; KRDI: Korean Dietary Reference Intakes; LARN: livelli di assunzione di riferimento di nutrienti; NIV: nutrient intake value; NNR: Nordic nutrition recommendations; NRV: nutrient reference values; OVD: odporúčané výživové dávky; PRI: population reference intake; PVD: priporočeni dnevni vnosi; RI: recommended intake; RDA: recommended dietary allowance; RDD: recomendiaciones dietéticas diarias; RDI: recommended dietary intake; RNI: recommended nutrient intake; RNP: requerimiento nutrimental promedio; RP: rekomenduotinus paros poreikias; RPN: rekomenduojamos paros maistinių medžiagų ir energijos normos; SI: safe intake; VNR: valores nutrimentales de referencia; WHO: World Health Organization; † Equivalent terms are used; ${ }^{1}$ inclusive of Belize, Costa Rica, El Salvador, Guatemala, Honduras, Nicaragua, and the Dominican Republic; ${ }^{2}$ inclusive of Cambodia, Indonesia, Laos, Malaysia, Myanmar, Philippines, Singapore, Thailand, and Vietnam; ${ }^{3}$ for NPNL women; ${ }^{4}$ for pregnant and lactating women.

\section{Establishing Nutrient Intake Values for Folate}

\subsection{Selection of Model Indicators for Folate Adequacy}

Selecting a reliable indicator for nutrient adequacy is a critical step in determining the ANR for a subpopulation. Ideally the indicator chosen should be reflective of a physiologic state representative of adequate intake in all individuals; resistant to short-term dietary intake changes and other environmental influences such as infection; easily measurable and non-invasive; elicit a dose-response relationship across a range of intakes; and be accepted worldwide to allow for harmonization of NIVs [13].

Folate requirements in most countries have been established based on concentrations of serum or erythrocyte folate known to be associated megaloblastic anemia - the clinical manifestation of folate deficiency. Several countries, namely Austria, Germany and Switzerland (abbreviated as the DACH countries) and France have chosen concentration of homocysteine (which increases when folate status is low) as an indicator of adequate intake on the basis of its association with CVD risk [17,30]. Although homocysteine concentration is considered a sensitive indicator, it is not specific for folate since it is influenced by nutritional status of other B-vitamins, one-carbon metabolism related nutrients and renal insufficiency [54]. Furthermore, a recent meta-analysis of randomized controlled trials found no significant effect of lowering homocysteine levels with folic acid supplementation on cardiovascular events [55]. In contrast, erythrocyte folate concentration appropriately fits the criteria as an indicator of adequacy. Erythrocyte folate concentration is a marker of long-term folate status (i.e., resistant to recent or transient changes in dietary folate intake), reflects tissue folate stores [56], and shows a dose-response relationship with intake. Erythrocyte folate cut-offs as an indicator of adequacy 
vary from country to country, ranging from $300 \mathrm{nmol} / \mathrm{L}$ to $327 \mathrm{nmol} / \mathrm{L}$ [26,28,50-52]. Conventionally, folate deficiency has been defined as a serum folate concentration $<3 \mathrm{ng} / \mathrm{mL}(6.8 \mathrm{nmol} / \mathrm{L})$ and an erythrocyte folate concentration $<140 \mathrm{ng} / \mathrm{mL}(317 \mathrm{nmol} / \mathrm{L})$, below which macrocytic anemia is most likely to appear (Folate cut-offs are originally reported in units of $\mathrm{ng} / \mathrm{mL}$. To obtain units in $\mathrm{nmol} / \mathrm{L}$ values have been multiplied by 2.265 ). These cut-offs were based on data generated from folate depletion studies conducted in a small number of subjects [57-59], and erythrocyte folate concentration levels obtained from patients presenting with megaloblastic anemia [60,61]. In addition, the risk of uracil misincorporation into DNA and chromosomal breakage has shown to increase in individuals with erythrocyte folate concentrations below $317 \mathrm{nmol} / \mathrm{L}$ [62].

A major difficulty in establishing a scientific consensus for folate deficiency lies in the existence of a number of methodological issues related to the measurement of blood folate. The microbiologic assay is the method of choice for many research laboratories, however, changes in the assay protocol over time have resulted in substantial inter-laboratory differences in the quantification of folate, presenting challenges in data interpretation across studies [63-65]. Standardization of folate measurement is needed for accurate assessment of blood folate status. Recent development of sophisticated mass spectrometric techniques have led to the development of serum folate reference measurement procedures [66-68]; however, similar procedures for erythrocyte blood folate are still in development [69-71]. Once established, there will be a need for clinical trials that relate accurately measured folate biomarker data to clinical outcomes.

\subsection{Consideration of Folate Bioavailability}

Bioavailability is an important factor to consider when estimating folate requirements due to differences in the absorption of naturally occurring food folate and the more bioavailable synthetic folic acid used in supplements and fortified foods. A number of studies used to determine NIVs have been based on data obtained from folic acid supplement trials, causing uncertainties in determining the equivalent amount of the less bioavailable food folate required to maintain adequate folate status. The U.S. DRI process has recommended the use of dietary folate equivalents (DFEs) for planning and evaluating the adequacy of folate intake. DFEs are defined as the amount of naturally occurring food folate plus 1.7 times the amount of folic acid from fortified foods [52]. Several countries, including a number of European countries, India, South Korea, China, Australia and New Zealand have also expressed NIVs in units of DFEs (Table 1). While adjusting for differences in folate bioavailability is particularly important in countries where folic acid has been added to the food supply, the bioavailability estimate for food folate derived from the DFE equation remains questionable. A thorough review of folate bioavailability is presented elsewhere in this special issue [72]. In summary, there are fairly large discrepancies in the bioavailability of naturally occurring food folate with values ranging from $30 \%$ [73] to $98 \%$ [74] relative to folic acid. These differences are likely attributed to the use of different test foods, difficulties in quantifying the amount of folate in these foods, and metabolic differences in the physiologic response between naturally occurring food folate and the synthetic, fully oxidized, monoglutamate form of folic acid. It should also be noted that a number of trials have shown that $[6 S]-5$-methyltetrahydrofolate in its monoglutamate form given as a supplement or microencapsulated in food results in a similar change in blood folate concentration to folic acid [75-77]. 
Further investigations are required to derive reasonably accurate and precise estimates of folate bioavailability. Recent efforts to scale up folic acid fortification in both developed and developing countries indicate that this should be a research priority.

\subsection{Genetic Variation in Requirements}

Recent advances in the field of genetics and nutrition have highlighted the importance of gene-diet interactions, and introduced the concept of applying genomic knowledge to population-based dietary recommendations. Currently NIVs for folate are targeted to the general and supposedly "normal" population. However, the identification of several genetic polymorphisms in folate metabolism has stimulated research on the impact of these variants on population health [78].

The C677T polymorphism in the enzyme methylenetetrahydrofolate reductase (MTHFR) is one of the most investigated genes in folate metabolism. For TT homozygous individuals, the polymorphism results in partial enzyme deficiency [78]. The distribution of the $T$ allele varies substantially among ethnic groups, with a lower prevalence of the $T T$ genotype among Sub-Saharan Africans (0\%-2\%), North American whites $(8 \%-14 \%)$ and Northern Europeans $(6 \%-14 \%)$ compared to Southern Europeans (15\%-24\%) and Hispanic populations (15\%-35\%) [78-80]. The TT genotype is associated with lower folate status by $10 \%-35 \%$ and elevated homocysteine concentrations [78]. Consequently folate requirements may be higher in persons with the $T T$ genotype, although differences in indicators of folate status among genotype groups appear to be greater when folate status is low [78,81-83]. Moreover, data on variability and the magnitude of the effect of the $T T$ genotype on requirements are lacking. Nonetheless, Mexico have set requirements based on the U.S. DRIs with an adjustment toward higher intake levels due to the increased frequency of the TT genotype in the Mexican population [39].

With the rapid pace of development in genome-wide technology, an increasing number of common genetic variants in folate metabolism will be identified and future research will continue to explore their link with common disorders. As a result, both the genetic and non-genetic variation in requirements within a population will need to be carefully considered in the future development of NIVs. Current evidence suggests that the allowance for variability used in setting INL98 levels may already act as a built-in safeguard for the presence of genetic variability within populations [84]. For example, Robitaille et al. [85] modeled the effect of MTHFR TT prevalence on the IOM RDA demonstrating that even when accounting for a large effect size of 50\% (i.e., 50\% higher requirement of dietary folate for individuals with a TT genotype), the RDA would only increase from $400 \mu \mathrm{g}$ DFE to $436 \mu \mathrm{g}$ DFE in a population with $20.3 \%$ TT genotyped individuals.

\subsection{Estimating Variability in Requirements}

Folate needs vary between individuals, yet information from which to obtain a reliable estimate of the variance or standard deviation of the ANR is limited. When the variance is not known for a nutrient, then a symmetrical distribution is assumed and a coefficient of variation (CV) can be applied — often this is equal to about $10 \%$. For folate, CVs vary widely; $10 \%$ has been used in Japan, the U.S. and Canada, 15\% in the DACH countries and the U.K., 20\% in the European Community and Mexico, and 25\% in the Netherlands and the Nordic countries (Denmark, Finland, Iceland, Norway 
and Sweden). Given the $\mathrm{INL}_{\mathrm{x}}$ is derived from the ANR and its distribution, these differences in the CV assumed has lead to some of the discrepancy in the $\mathrm{INL}_{98}$ set among countries. For example, both Japan and the Netherlands have set the same ANR value of $200 \mu \mathrm{g}$ DFE, however Japan have assigned a CV of $10 \%$ [36], while the Netherlands have assigned a CV of $25 \%$ [50] leading to a discrepancy of $60 \mu \mathrm{g}$ DFE in their INL 98 . In the face of limited data, the uncertainty surrounding the variation in requirements leads to the potential to over-estimate the proportion of inadequate intakes if the $\mathrm{CV}$ is set too low compared to the actual variability in requirements of a population, or under-estimate the proportion of inadequate intakes if set too high.

The traditional approach to determining nutrient requirements is to test a range of nutrient intakes (preferably from foods) in the same individuals using a controlled diet over a sufficient duration to elicit a response in the nutritional indices measured. Often participant numbers in these types of controlled metabolic-unit depletion/repletion and nutrient balance studies are small and consequently, inter-individual variation in requirements cannot be determined. Although challenging, rigorous large-scale controlled-diet studies on free-living subjects are needed to allow for a reasonable approximation of the variability in requirements and the distribution of intakes.

\section{Nutrient Intake Values for Folate in Use around the World}

NIVs for folate for NPNL, pregnant and lactating women by country are listed in Table 2. While several countries have established their own NIVs for folate, many others including the WHO have either shared or adopted values from other countries (Table 1). The most commonly adopted NIVs are those set by the IOM in 1998. Although folate NIVs for pregnant and lactating women are consistently higher than for NPNL women, NIVs vary among countries and the use of DFE units is inconsistent. Moreover, many countries have only specified a value equivalent to the INL 98 .

Table 2. Nutrient intake values for non-pregnant, non-lactating (NPNL), pregnant, and lactating women by country.

\begin{tabular}{|c|c|c|c|c|c|c|c|}
\hline \multirow{2}{*}{ Country } & \multirow{2}{*}{ Units } & \multicolumn{2}{|c|}{ NPNL } & \multicolumn{2}{|c|}{ Pregnant } & \multicolumn{2}{|c|}{ Lactating } \\
\hline & & ANR & INL $_{98}$ & ANR & INL $_{98}$ & ANR & INL $_{98}$ \\
\hline Australia and New Zealand ${ }^{1}$ & $\mu \mathrm{g}$ DFE & 320 & 400 & 520 & 600 & 450 & 500 \\
\hline Austria, Germany, and Switzerland ${ }^{1}$ & $\mu \mathrm{g}$ DFE & - & 400 & - & 600 & - & 600 \\
\hline Austria, Germany, and Switzerland ${ }^{1,2}[86]$ & $\mu \mathrm{g}$ DFE & 220 & 300 & 420 & 550 & 340 & 450 \\
\hline Belgium & $\mu \mathrm{g}$ & - & 200 & - & 400 & - & 350 \\
\hline Brazil & $\mu \mathrm{g}$ & - & 240 & - & 355 & - & 295 \\
\hline Bulgaria & $\mu \mathrm{g}$ DFE & - & 400 & - & 600 & - & 500 \\
\hline Central America ${ }^{3}$ and Panama & $\mu \mathrm{g}$ & - & 170 & - & $370-470$ & - & 270 \\
\hline China & $\mu \mathrm{g}$ DFE & 320 & 400 & 520 & 600 & 450 & 500 \\
\hline Colombia & $\mu \mathrm{g}$ & - & 160 & - & 460 & - & 360 \\
\hline Croatia & $\mu \mathrm{g}$ DFE & - & 200 & - & 600 & - & 500 \\
\hline Cuba & $\mu \mathrm{g}$ DFE & - & 400 & - & 600 & - & 500 \\
\hline Denmark, Iceland and Sweden ${ }^{1}$ & $\mu \mathrm{g}$ & 200 & $400^{5}$ & - & 500 & - & 500 \\
\hline Estonia & $\mu \mathrm{g}$ & - & $400^{5}$ & - & 500 & - & 500 \\
\hline European Community & $\mu \mathrm{g}$ & 140 & 200 & - & 400 & - & 350 \\
\hline Finland $^{1}$ & $\mu \mathrm{g}$ & 200 & $400^{5}$ & - & 400 & - & 400 \\
\hline
\end{tabular}


Table 2. Cont.

\begin{tabular}{|c|c|c|c|c|c|c|c|}
\hline France $^{1}$ & $\mu \mathrm{g}$ & - & $300^{6}$ & - & $400^{6}$ & - & $400^{6}$ \\
\hline Greece & $\mu \mathrm{g}$ & 140 & 200 & - & 400 & - & 350 \\
\hline Hungary ${ }^{1}$ & $\mu \mathrm{g}$ & - & $200^{6}, 400^{6,7}$ & - & $400^{6}, 600^{6,7}$ & - & $350^{6}, 500^{6,7}$ \\
\hline India & $\mu \mathrm{g}$ DFE & - & 200 & - & 500 & - & 300 \\
\hline Ireland ${ }^{1}$ & $\mu \mathrm{g}$ & - & 300 & - & 500 & - & 400 \\
\hline Italy ${ }^{1}$ & $\mu \mathrm{g}$ DFE & 320 & 400 & 520 & 600 & 450 & 500 \\
\hline Japan & $\mu \mathrm{g}$ & 200 & 240 & 370 & 440 & 280 & 340 \\
\hline Latvia & $\mu \mathrm{g}$ & - & 300 & - & 400 & - & 300 \\
\hline Lithuania & $\mu \mathrm{g}$ & - & 300 & - & 400 & - & 480 \\
\hline Mexico & $\mu \mathrm{g}$ DFE & 320 & $460^{6}$ & 520 & $750^{6}$ & 450 & $650^{6}$ \\
\hline Norway ${ }^{1}$ & $\mu \mathrm{g}$ & 200 & $400^{4}$ & - & 400 & - & 400 \\
\hline Poland ${ }^{1}$ & $\mu \mathrm{g}$ DFE & 320 & 400 & 520 & 600 & 450 & 500 \\
\hline Republic of Macedonia & $\mu \mathrm{g}$ & - & 200 & - & 400 & - & 500 \\
\hline $\begin{array}{c}\text { Republica Srpska, Bosnia and } \\
\text { Herzegovina }\end{array}$ & $\mu \mathrm{g}$ DFE & - & 400 & - & 600 & - & 500 \\
\hline Russian Federation & $\mu \mathrm{g}$ & - & 400 & - & 600 & - & 500 \\
\hline Slovakia & $\mu \mathrm{g}$ & - & 200 & - & 400 & - & 300 \\
\hline Slovenia & $\mu \mathrm{g}$ DFE & - & 400 & - & 600 & - & 600 \\
\hline South Korea & $\mu \mathrm{g}$ DFE & 320 & 400 & 520 & 600 & 450 & 550 \\
\hline Southeast Asia Region ${ }^{4}$ & $\mu \mathrm{g}$ & - & 400 & - & 600 & - & 500 \\
\hline Spain ${ }^{1}$ & $\mu \mathrm{g}$ & - & 300 & - & 500 & - & 400 \\
\hline The Netherlands ${ }^{1}$ & $\mu \mathrm{g}$ DFE & 200 & 300 & - & $400^{6}$ & - & $400^{6}$ \\
\hline United Kingdom ${ }^{1}$ & $\mu \mathrm{g}$ & 150 & 200 & - & 300 & - & 260 \\
\hline United States and Canada ${ }^{1}$ & $\mu \mathrm{g}$ DFE & 320 & 400 & 520 & 600 & 450 & 500 \\
\hline United States 1989 [87] & $\mu \mathrm{g}$ & - & 180 & - & 400 & - & $280^{8}, 260^{9}$ \\
\hline United States 1980 [88] & $\mu \mathrm{g}$ & - & 400 & - & 800 & - & 500 \\
\hline United States 1974 [89] & $\mu \mathrm{g}$ & - & 400 & - & 800 & - & 600 \\
\hline United States 1968 [90] & $\mu \mathrm{g}$ & - & 400 & - & 800 & - & 500 \\
\hline WHO/FAO & $\mu \mathrm{g}$ DFE & 320 & 400 & 520 & 600 & 450 & 500 \\
\hline WHO/FAO 1988 [91] & $\mu \mathrm{g}$ & - & $170^{6}$ & - & $370-400^{6}$ & - & $270^{6}$ \\
\hline
\end{tabular}

NR: average nutrient requirement; DFE: dietary folate equivalents; FAO: Food and Agriculture Organization; INL: individual nutrient level; NPNL: non-pregnant, non-lactation; WHO: World Health Organization; ${ }^{1}$ These countries recommend an additional intake of $400 \mu \mathrm{g}$ folic acid per day from supplements and/or fortified foods for women who are capable of becoming pregnant or planning a pregnancy, or who have an unbalanced poor diet, or because women are unlikely to meet the NIV, for the prevention of neural tube defects. Poland does not specify a dosage for folic acid supplementation [16,34,50,52,86,92,93]. ${ }^{2}$ Proposed values to be approved August 2013; ${ }^{3}$ Inclusive of Belize, Costa Rica, El Salvador, Guatemala, Honduras, Nicaragua, and the Dominican Republic; ${ }^{4}$ Inclusive of Cambodia, Indonesia, Laos, Malaysia, Myanmar, Philippines, Singapore, Thailand, and Vietnam; ${ }^{5}$ The Nordic recommendations presented are for women of reproductive potential; ${ }^{6}$ the equivalent of a safe intake level is used rather than an $\mathrm{INL}_{98} ;{ }^{7} \mathrm{INL}_{98}$ when cereals are supplemented; ${ }^{8} 1$ st 6 months; ${ }^{9}$ 2nd 6 months.

\subsection{Non-Pregnant, Non-Lactating (NPNL) Women}

The INL98 for NPNL women varies between $200 \mu \mathrm{g}$ and $460 \mu \mathrm{g}$ DFE per day. Early work by Herbert in 1962 in one adult male and three adult females established that a minimum of $50 \mu \mathrm{g}$ folic 
acid per day was required to recover normal hematology after a prolonged folate deficient diet $[58,94]$. The European Community have used this data to establish ANR for folate of $140 \mu \mathrm{g} / \mathrm{day}$ with the reasoning that the ANR would be somewhat higher than the minimum $50 \mu \mathrm{g}$ folic acid/day — setting the value at $70 \mu \mathrm{g}$ folic acid/day multiplied by a bioavailability correction factor of 2 . Later work published by Sauberlich et al. in 1987 [95] and O'Keefe et al. in 1995 [96] generated from controlled metabolic studies, suggested higher intake levels of between $200 \mu \mathrm{g}$ and $320 \mu \mathrm{g}$ dietary folate/day were required to maintain status and prevent deficiency in NPNL women. The IOM (U.S. and Canada) and the Netherlands have considered much of the same data in determining NIVs for NPNL women, including the studies of Sauberlich et al. [95] and O'Keefe et al. [96] together with studies of Milne et al. [97] and Jacob et al. [98]. The IOM chose an ANR of $320 \mu \mathrm{g}$ DFE/day, based primarily on data from the study of O'Keefe et al. [96], which demonstrated that at this intake level, 3 out of 5 women had an erythrocyte folate concentration below $305 \mathrm{nmol} / \mathrm{L}$ and serum folate below $7 \mathrm{nmol} / \mathrm{L}$, and 2 out of 5 women had a homocysteine concentration greater than $16 \mathrm{nmol} / \mathrm{L}$ with another participant above $14 \mathrm{nmol} / \mathrm{L}$. These data suggested that approximately half of women would have a normal erythrocyte folate level at an intake of $320 \mu \mathrm{g}$ DFE/day [52]. In contrast, the Netherlands chose a lower ANR of $200 \mu \mathrm{g}$ DFE/day, relying primarily on data from the depletion-repletion study of Sauberlich et al. [95], in which $200 \mu \mathrm{g}$ of folate from food sources resulted in stabilization of plasma folate concentration in 2 out of 3 subjects [50,95]. Data from the study of Milne et al. [97] of adult men was also used to support the Netherland's ANR of $200 \mu \mathrm{g}$ DFE/day. Finally, the NIVs for folate set by the DACH countries are currently based on data from O'Keefe et al. [96], but are in the process of being revised toward lower NIVs on the basis of data from the studies of Sauberlich et al. [95] and Milne et al. [86,97].

The small study sample sizes of between 3 and 6 participants per test group, and the uncertainties surrounding folate bioavailability, particularly with the use of supplemental folic acid, leaves little confidence that these values are a true representation of the ANR. Another flaw of these studies is the inadequate duration to observe a plateau in erythrocyte folate response. The study of O'Keefe et al. [96] was conducted over 10 weeks (70 days) with subjects consuming a consistent diet, while the 13-week (91 day) study of Sauberlich et al. [95] involved a 4-week depletion diet followed by three 3-week repletion intervals whereby participants were provided with additional amounts of food folates along with graded doses of supplemental folic acid. Recent efforts to assess long-term blood folate responses to supplemental folic acid have shown that even with a relatively small daily intake of folic acid (140 $\mu \mathrm{g}$ /day) over a 40 -week period, erythrocyte folate concentrations continued to increase [99]. Thus, the studies described above may have underestimated the biochemical response to controlled folate intakes and potentially overestimated folate requirements.

Interestingly, nutritional epidemiological evidence consistently demonstrates population intakes that are inconsistent with rates of folate deficiency. For example, most observational population studies have reported average dietary folate intakes ranging between 200 and $300 \mu \mathrm{g} /$ day (Table 3); yet in a comprehensive review, Metz [100] found little evidence of anemia attributable to folate and vitamin B12 worldwide, with many studies showing no association between blood folate concentration and anemia even when the prevalence of low blood folate concentration is such that a significant association would be expected. It is conceivable that a discrepancy in the prevalence of low folate intakes, low folate status, and megaloblastic anemia exists due to measurement errors in dietary intake 
and laboratory assessment of folate status as well as a potential overestimation of folate requirements as previously noted.

To date, despite compelling evidence to support recommendations for women who are capable of becoming pregnant or who are planning a pregnancy to consume $400 \mu \mathrm{g}$ of supplement folic acid/day for the prevention of NTDs, NIVs for women of reproductive potential in most countries are based on prevention of hematological abnormalities. A number of countries have established recommendations in addition their NIVs for the prevention of NTDs, recommending an additional $400 \mu \mathrm{g} /$ day of folic acid from either supplements or a combination of supplements or fortified foods [16,34,50,52,86,92,93]. One exception is the Nordic countries, while still recommending an additional intake of $400 \mu \mathrm{g} / \mathrm{day}$ from supplemental folic acid [92,93], the Nordic countries have specifically set an INL 98 of $400 \mu \mathrm{g} /$ day for women of reproductive potential to reduce their chance of having an NTD-affected pregnancy versus the Nordic INL ${ }_{98}$ of $300 \mu \mathrm{g} /$ day for adults [26]. Establishing an ANR for NPNL women on the basis of NTD prevention remains challenging, as there are a number of uncertainties surrounding the relationship among NTD risk, folate intake (natural food folate and folic acid), and erythrocyte folate concentration. The IOM considered data from two retrospective observational studies [101,102], showing a decrease in the risk of NTDs with increasing intake of dietary folate up to $400 \mu \mathrm{g}$ DFE/day [52]. There were a number of limitations in these studies including relatively small participant sample size. At present, the minimum intake of folic acid to increase erythrocyte folate to concentrations associated with the lowest risk of NTDs is unknown $[8,103]$.

Table 3. Mean and median intakes of folate for women from population survey data by country.

\begin{tabular}{|c|c|c|c|c|c|c|c|c|}
\hline Country & Year & Method & Group & $N$ & Mean & Median & Units & Reference. \\
\hline \multirow[t]{2}{*}{ Australia } & 1995 & $24 \mathrm{~h} \mathrm{RC}$ & 19-24 year & 575 & 233 & 217 & $\mu \mathrm{g}$ & [104] \\
\hline & & & 25-44 year & 2385 & 227 & 210 & $\mu \mathrm{g}$ & \\
\hline \multirow[t]{2}{*}{ Canada } & 2004 & $24 \mathrm{~h} \mathrm{RC}$ & $19-30$ year & 1854 & $415^{1}$ & $401^{1}$ & $\mu \mathrm{g}$ DFE & [105] \\
\hline & & & $31-50$ year & 2686 & $423^{1}$ & $411^{1}$ & $\mu \mathrm{g}$ DFE & \\
\hline \multirow[t]{3}{*}{ Denmark } & 1995 & 7 day DR & 19-24 year & 100 & 244 & 220 & $\mu \mathrm{g}$ & [106] \\
\hline & & & 25-34 year & 161 & 266 & 232 & $\mu \mathrm{g}$ & \\
\hline & & & $35-44$ year & 158 & 234 & 239 & $\mu \mathrm{g}$ & \\
\hline \multirow[t]{5}{*}{ Finland } & 1997 & $24 \mathrm{~h} \mathrm{RC}$ & $25-74$ year & 325 & $209^{2,3}$ & & $\mu \mathrm{g}$ & [107] \\
\hline & 2007 & $48 \mathrm{~h} \mathrm{RC}$ & $25-34$ year & 180 & $216^{3}$ & & $\mu \mathrm{g}$ & [108] \\
\hline & & & $35-44$ year & 211 & $217^{3}$ & & $\mu \mathrm{g}$ & \\
\hline & & $18 \mathrm{~b} P C \& \& 2$ dou $F D P$ & $25-74$ year & 641 & $240^{3,4}$ & $230^{3,4}$ & $\mu \mathrm{g}$ & \\
\hline & & 48 h RC \& 3 day EDR & & & $310^{2,3,4}$ & $280^{2,3,4}$ & $\mu \mathrm{g}$ & \\
\hline \multirow[t]{5}{*}{ Germany } & 1997-1999 & DH & $18-79$ year & 2267 & & 229 & $\mu \mathrm{g}$ & [109] \\
\hline & & & & & & $238^{2}$ & $\mu \mathrm{g}$ & \\
\hline & 2005-2006 & DH & 19-24 year & 510 & 318 & 257 & $\mu \mathrm{g}$ DFE & [110] \\
\hline & & & 25-34 year & 972 & 311 & 258 & $\mu \mathrm{g}$ DFE & \\
\hline & & & $35-50$ year & 2694 & 285 & 255 & $\mu \mathrm{g}$ DFE & \\
\hline \multirow[t]{2}{*}{ Ireland } & 1997-1999 & 7 day DR & $18-35$ year & 269 & $247^{2}$ & $216^{2}$ & $\mu \mathrm{g}$ & [111] \\
\hline & & & $36-50$ year & 286 & $267^{2}$ & $228^{2}$ & $\mu \mathrm{g}$ & \\
\hline
\end{tabular}


Table 3. Cont.

\begin{tabular}{|c|c|c|c|c|c|c|c|c|}
\hline \multirow[t]{2}{*}{ New Zealand } & 1997 & $24 \mathrm{~h} \mathrm{RC}$ & 19-24 year & 209 & 202 & 195 & $\mu \mathrm{g}$ & [112] \\
\hline & & & 25-44 year & 1205 & 220 & 213 & $\mu \mathrm{g}$ & \\
\hline \multirow{2}{*}{ Spain } & 1992-1993 & $24 \mathrm{~h} \mathrm{RC}$ & 18-34 year & 431 & 282 & 257 & $\mu \mathrm{g}$ & [113] \\
\hline & & $\& \mathrm{FFQ}$ & 35-49 year & 323 & 317 & 291 & $\mu \mathrm{g}$ & \\
\hline \multirow[t]{2}{*}{ Sweden } & 1997-1998 & 7 day EDR & 25-34 year & 132 & 209 & 211 & $\mu \mathrm{g}$ & [114] \\
\hline & & & 35-44 year & 132 & 206 & 201 & $\mu \mathrm{g}$ & \\
\hline \multirow[t]{8}{*}{ The Netherlands } & 1992 & 2 day DR & 19-21 year & 107 & 243 & 236 & $\mu \mathrm{g}$ & [115] \\
\hline & & & $22-49$ year & 1493 & 234 & 224 & $\mu \mathrm{g}$ & \\
\hline & 1993-1996 & FFQ & $20-65$ year & 1160 & 192 & & $\mu \mathrm{g}$ & [116] \\
\hline & 2003 & $24 \mathrm{~h} \mathrm{RC}$ & 19-30 year & 398 & 153 & & $\mu \mathrm{g}$ & [117] \\
\hline & $2007-2010$ & $24 \mathrm{~h} \mathrm{RC}$ & 19-30 year & 347 & & 216 & $\begin{array}{c}\mu \mathrm{g} \\
\mathrm{DFE}\end{array}$ & [118] \\
\hline & & & & & & $249^{2}$ & $\begin{array}{c}\mu \mathrm{g} \\
\mathrm{DFE}\end{array}$ & \\
\hline & & & $31-50$ year & 351 & & 242 & $\begin{array}{c}\mu \mathrm{g} \\
\mathrm{DFE}\end{array}$ & \\
\hline & & & & & & $282^{2}$ & $\begin{array}{c}\mu \mathrm{g} \\
\mathrm{DFE}\end{array}$ & \\
\hline \multirow[t]{11}{*}{ United Kingdom } & 1986-1987 & 7 day WDR & 16-24 year & 189 & 198 & 194 & $\mu \mathrm{g}$ & [119] \\
\hline & & & 25-34 year & 253 & 206 & 198 & $\mu \mathrm{g}$ & \\
\hline & & & $35-49$ year & 385 & 220 & 212 & $\mu \mathrm{g}$ & \\
\hline & 2000-2001 & 7 day WDR & 19-24 year & 104 & 229 & 225 & $\mu \mathrm{g}$ & [120] \\
\hline & & & & & $248^{2}$ & $232^{2}$ & $\mu \mathrm{g}$ & \\
\hline & & & 25-34 year & 210 & 233 & 229 & $\mu \mathrm{g}$ & \\
\hline & & & & & $249^{2}$ & $233^{2}$ & $\mu \mathrm{g}$ & \\
\hline & & & $35-49$ year & 318 & 255 & 251 & $\mu \mathrm{g}$ & \\
\hline & & & & & $280^{2}$ & $258^{2}$ & $\mu \mathrm{g}$ & \\
\hline & 2008-2010 & 4 day EDR & 19-64 year & 461 & 232 & 219 & $\mu \mathrm{g}$ & [121] \\
\hline & & & & & $264^{2}$ & $234^{2}$ & $\mu \mathrm{g}$ & \\
\hline \multirow[t]{6}{*}{ United States } & 1988-1994 & $24 \mathrm{~h} \mathrm{RC}$ & 20-39 year & 2260 & 217 & 178 & $\mu \mathrm{g}$ & [122] \\
\hline & 1999-2000 & $24 \mathrm{~h} \mathrm{RC}$ & 20-39 year & 356 & 294 & 270 & $\mu \mathrm{g}$ & [122] \\
\hline & 2003-2006 & $24 \mathrm{~h} \mathrm{RC}$ & 19-30 year & 914 & $460^{1}$ & & $\begin{array}{c}\mu \mathrm{g} \\
\mathrm{DFE}\end{array}$ & [123] \\
\hline & & & & & $645^{1,2}$ & & $\begin{array}{c}\mu \mathrm{g} \\
\mathrm{DFE}\end{array}$ & \\
\hline & & & $31-50$ year & 1350 & $470^{1}$ & & $\begin{array}{c}\mu \mathrm{g} \\
\mathrm{DFE}\end{array}$ & \\
\hline & & & & & $714^{1,2}$ & & $\begin{array}{c}\mu \mathrm{g} \\
\mathrm{DFE}\end{array}$ & \\
\hline
\end{tabular}

DFE: dietary folate equivalent; DH: diet history; DR: diet record; EDR: estimated diet record; FFQ: food frequency questionnaire; RC: recall; WDR: weighed diet record; ${ }^{1}$ intake is measured following mandatory fortification of the food supply with folic acid; ${ }^{2}$ inclusive of intake from supplements; ${ }^{3}$ adjusted for folate losses in cooking; ${ }^{4}$ excluding under-reporters.

Observational studies of dietary intake are subject to systematic errors that often lead to an underestimation of usual folate intakes due to underreporting of food intake and inaccuracies in food composition databases, secondary to methodological issues in analysis $[52,124,125]$. Furthermore folic 
acid intake from supplements and fortified foods, an important contributor to biochemical folate status, is not always considered in reports of dietary intake [125]. Thus determination of NIVs based on metabolic studies of controlled folate intake may result in higher values than those based on observational studies of dietary intake. The U.S. RDA for women for folate was lowered from $400 \mu \mathrm{g}$ /day in the ninth edition (1980) to $180 \mu \mathrm{g} /$ day in the tenth edition (1989) based on the recognition that observed population intakes of roughly $3 \mu \mathrm{g} / \mathrm{kg}$ maintained adequate folate status in approximately $90 \%$ of the population [87]. In 1998 the U.S. RDA was increased once again to $400 \mu \mathrm{g}$ DFE/day based on data from controlled intake studies [52]. A number of countries have used observational data from population studies to set requirements including the UK, Belgium, France, and the Nordic countries.

The disparity between requirements based on studies of controlled folate intake versus observational survey data is prevalent and can be a significant hindrance to the way science informs and influences public health policymaking (e.g., food fortification programs). The ongoing development and validation of innovative dietary assessment methods (e.g., internet-based assessment, and the use of digital cameras and cellular phones), and improvements in analytical measurement of food and tissue folate levels will provide more accurate and meaningful data. Until then, caution is warranted in interpreting intake-status results from epidemiological studies.

\subsection{Pregnant Women}

Because of ethical considerations, depletion-repletion studies in pregnant women are lacking. Consequently, folate requirements for pregnant women are largely based on findings of population-based supplementation trials conducted in the 1960s [4,126-128] and a more recent controlled metabolic study aimed to evaluate the adequacy of the current folate requirements in a group of pregnant women [129]. Estimates generated from these earlier supplementation trials determined that the minimum daily requirement of supplemental folic acid in pregnant women was approximately $100 \mu \mathrm{g} /$ day [4,126]; however, if megaloblastic anemia was more common in the population (i.e., in a population with suboptimal folate intake), a daily supplement of $300 \mu \mathrm{g}$ folic acid/day was closer to the minimum requirement, particularly in late pregnancy [7,127,128]. Specifically, Hansen and Rybo [4] demonstrated that while supplementation with $50 \mu \mathrm{g}$ folic acid/day taken in the last trimester of pregnancy was not sufficient to maintain maternal folate stores, $100 \mu \mathrm{g}$ folic acid/day was found to be adequate to prevent against a decline in erythrocyte folate concentration, however $15 \%$ of study participants had serum folate levels below $2 \mathrm{ng} / \mathrm{mL}$. Willoughby and Jewel [128] found that $100 \mu \mathrm{g}$ folic acid/day was inadequate to prevent a serum folate concentration below $3 \mathrm{ng} / \mathrm{mL}$ in $33 \%$ of women compared to only $5 \%$ of women supplemented with $300 \mu \mathrm{g}$ folic acid/day. Furthermore, none of the participants consuming $300 \mu \mathrm{g}$ folic acid/day presented with megaloblastic anemia compared to $2 \%$ of the group supplemented with $100 \mu \mathrm{g}$ folic acid/d. In a larger study of 3599 pregnant women, Willoughby [127] found that supplementation with $300 \mu \mathrm{g}$ folic acid/d reduced the rate of megaloblastic anemia to $0.3 \%$ compared with $0.7 \%$ reported in a similar study of women $(n=350)$ supplemented with $100 \mu \mathrm{g}$ /day. In contrast, Chanarin et al. [126] showed that supplementation with $100 \mu \mathrm{g}$ folic acid/day was sufficient to maintain both serum and erythrocyte folate concentration during the last trimester of pregnancy in a group of 206 British women. The discrepancies in these 
findings may be explained by differences in dietary folate intakes. However, the dietary intakes of study participants were not assessed, with the exception of Chanarin et al., who determined an average baseline dietary folate intake of $676 \mu \mathrm{g}$ of total folate/day [130]. This unexpectedly high value was derived from 24-h food collection obtained from a subsample of participants (16 of 206 women). Given that these studies were conducted prior to folic acid fortification of the food supply, usual dietary folate intakes were likely to be lower, ranging from 200 to $300 \mu \mathrm{g} /$ day [131].

Caudill et al. conducted the only controlled metabolic study of folate intake [129]. Pregnant participants $(n=12)$ in their second trimester and non-pregnant controls were randomly assigned to supplemental folic acid intakes of either 330 or $730 \mu \mathrm{g} /$ day, in addition to a diet containing $120 \mu \mathrm{g} / \mathrm{day}$ of dietary folate, for 12-weeks ( 84 days). No differences were detected in blood folate status between pregnant women and non-pregnant controls within the same supplementation group. Moreover, no women presented with a low serum $(<13.6 \mathrm{nmol} / \mathrm{L})$ or erythrocyte $(<364 \mathrm{nmol} / \mathrm{L})$ folate throughout the duration of the study. The authors concluded that $450 \mu \mathrm{g} /$ day (dietary folate plus supplemental folic acid), equivalent to $600 \mu \mathrm{g} \mathrm{DFE} /$ day, was sufficient to maintain folate status in pregnant women. Using the equation for DFEs proposed by the IOM, this value is actually equivalent to $680 \mu \mathrm{g}$ DFE/day. From these data along with the findings of the population studies, the IOM derived their ANR by adding $200 \mu \mathrm{g}$ DFE to the ANR for NPNL women $(320 \mu \mathrm{g} /$ day DFE) to provide an ANR for pregnant women of $520 \mu \mathrm{g}$ DFE/day. Assuming a CV of $10 \%$ and based on the support of the controlled metabolic study, the $\mathrm{INL}_{98}$ was set at $600 \mu \mathrm{g}$ DFE/day [52]. Similarly, a number of other countries including the European Community, the DACH countries, and the Netherlands, have established NIVs based primarily on data from the population-based supplement trials with an addition of $200 \mu \mathrm{g}$ folate added to their NIVs for NPNL women [28,50,86]; however differences in NIVs for pregnant women among these countries ranging from 400 to $600 \mu \mathrm{g} /$ day have arisen directly from differences in NIVs set for NPNL women.

In contrast, several Nordic countries (Denmark, Sweden, and Iceland) have established a slightly lower recommendation of $500 \mu \mathrm{g}$ /day [26] on the basis that requirements would not be as high as the minimum dose of $600 \mu \mathrm{g}$ DFE/day in the study of Caudill et al. [129], particularly given the observed increase in erythrocyte folate status. India has also set their $\mathrm{INL}_{98}$ of $500 \mu \mathrm{g} \mathrm{DFE} / \mathrm{day}$ although this value was based on the country-specific findings of a supplementation trial in 200 Indian pregnant women assigned to $60 \mathrm{mg}$ of elemental iron with or without folic acid at levels of 100, 200, or $300 \mu \mathrm{g} /$ day [132]. While a daily intake of $100 \mu \mathrm{g}$ folic acid was sufficient to maintain erythrocyte folate concentrations, mean birth-weight was significantly higher in the $300 \mu \mathrm{g}$ folic acid/day group versus the iron only group. A cross-sectional study of a group of unsupplemented women presented in the same article reported $23 \%$ and $64 \%$ of women had a serum folate below $3 \mathrm{ng} / \mathrm{mL}$ in the first and third trimester of pregnancy, respectively. Based on these findings, it was recommended that pregnant women would require an additional $300 \mu \mathrm{g}$ DFE/day - although despite the use of DFE units, it does not appear that an adjustment for the bioavailability of supplemental folic acid was made. Finally, Finland and Norway adapted one of the lowest recommendations of $400 \mu \mathrm{g} /$ day, with the reasoning that folate deficiency is rare and adoption of a higher level (as specified in the Nordic Nutrition Recommendations) would require the use of folic acid supplements during pregnancy and lactation [29]. 
Identification of alternative biomarkers of normal folate status that are sensitive to change and specific for folate inadequacy would be highly valuable in contributing to our understanding of the physiologic changes of pregnancy and the influence of dietary folate intake. Some researchers have proposed that the rate of urinary folate catabolite excretion reflects the role of folate in DNA biosynthesis and cellular turnover; therefore, urinary folate catabolites have been suggested as a potential indicator of folate requirements [133]. Specifically, McPartlin et al. [133] reported significantly greater urinary excretion of folate catabolites in the second and third trimester than in the first trimester, post-partum or NPNL state. Using a 50\% bioavailability factor for dietary folate, the authors calculated an extra demand for dietary folate of about 200-300 $\mu \mathrm{g}$ /day during pregnancy. In contrast, the controlled metabolic unit study conducted by Caudill et al. [129,134], found no significant differences in mean folate catabolite excretion between pregnant women in the second trimester and non-pregnant controls; however catabolite excretion was significantly higher in pregnant and non-pregnant women consuming 850 versus $450 \mu \mathrm{g}$ folate/day [134]. It was also noted that the pregnant women consuming $450 \mu \mathrm{g}$ folate/day experienced a decline in urinary catabolite excretion from baseline compared to their non-pregnant counterparts. This decline in urinary folate catabolite excretion may reflect a decrease in supplemental folate intake rather than folate requirement. Prior to the study, 10 out of 12 pregnant women were consuming folic acid supplements between 400 and $1000 \mu \mathrm{g} /$ day [129]. Whereas in the study of McPartlin et al. folate intake was only controlled up to $18 \mathrm{~h}$ before the collection of the 24-h urine sample and folic acid supplement use was not reported [133]. Current evidence cannot rule out whether the differences observed between these two studies are due to the different gestational periods of the women or are a reflection of prior supplemental intake. Additional work from metabolic controlled studies measuring changes in urinary folate catabolite excretion throughout pregnancy under conditions of inadequate folate intake to optimal intake levels are needed.

Other health outcomes related to maternal folate intake and status during pregnancy have been examined, with several studies finding a relation with birth weight and gestational age [135-140] whereas other have not [141]. In a recent meta-analysis, increased folate intake was found to be significantly associated with birth weight in a dose-dependent manner, but had no effect on placental weight or length of gestation [142]. Although data related to such perinatal outcomes are of potential interest, the inconsistent findings demonstrate the multi-factorial nature of these outcomes.

\subsection{Lactating Women}

Unlike NIVs for NPNL and pregnant women that are based on maintenance of blood folate status, NIVs for lactating women are often calculated as the sum of folate requirements of NPNL women and the amount of folate lost in breast-milk, with adjustments made for bioavailability. In doing so, variation in NIVs among countries can be partly attributed to differences in NIVs for NPNL women, and partly to differences in bioavailability adjustment factors and estimations of human milk folate content and volume [143]. Finland, Norway and France have not set NIVs specifically for lactating women, and have assigned NIVs using the same rationale as for pregnant women.

Table 4 shows the data used and calculations made by a number of countries to determine folate NIVs for lactating women based on extrapolation of human milk folate concentrations. Due to 
analytical difficulties, early measurements of human milk folate content were underestimated [52]. The U.K. based its NIV for lactating women on the study of Ek [144] published in 1983 which demonstrated a steady rise in milk folate concentration from $6 \mu \mathrm{g} / \mathrm{L}$ at 0 months after parturition up to $55 \mu \mathrm{g} / \mathrm{L}$ at 3 months after parturition; however, higher average milk folate values (average of $85 \mu \mathrm{g} / \mathrm{L}$ ) were reported by Smith et al. in 1985 [145]. Later studies published include those of: Brown et al. [146], which reported a mean concentration of $85.3 \mu \mathrm{g} / \mathrm{L}$ in 180 samples from 16 women; O'Connor et al. [147], which reported slightly higher values between 90 and $110 \mu \mathrm{g} / \mathrm{L}$ in samples from four women after optimizing sample pre-treatment; and Lim et al. [148], which reported a mean concentration of $86 \mu \mathrm{g} / \mathrm{L}$ in 84 human milk samples. These three studies are cited in the reports of the IOM and the Netherlands although it is unclear why the Netherlands used a lower milk folate concentration of $60 \mu \mathrm{g} / \mathrm{L}$. Human milk folate concentrations ranging between 70 and $110 \mu \mathrm{g} / \mathrm{L}$ have been confirmed in more recent studies using appropriate sampling techniques and pretreatment protocols [149-152].

Table 4. Data used to derive nutrient intake values (NIVs) for lactating women from breast-milk losses of folate by country ${ }^{1}$.

\begin{tabular}{ccccccc}
\hline Country & $\begin{array}{c}\text { Milk Folate } \\
\text { Concentration }\end{array}$ & $\begin{array}{c}\text { Daily Milk } \\
\text { Production }\end{array}$ & $\begin{array}{c}\text { Losses } \\
\text { Per Day }\end{array}$ & $\begin{array}{c}\text { Adjustment for } \\
\text { Bioavailability }\end{array}$ & $\begin{array}{c}\text { Addition in } \\
\text { Requirement }\end{array}$ & $\begin{array}{c}\text { Added to ANR } \\
\text { or INL }_{\mathbf{9 8}}\end{array}$ \\
\hline $\begin{array}{c}\text { Austria, Germany } \\
\text { and Switzerland }\end{array}$ & $80 \mu \mathrm{g} / \mathrm{L}$ & $750 \mathrm{~mL} /$ day & $60 \mu \mathrm{g} /$ day & $50 \%$ & $120 \mu \mathrm{g}$ DFE/day & ANR \\
$\begin{array}{c}\text { European } \\
\text { Community }\end{array}$ & $50-100 \mu \mathrm{g} / \mathrm{L}$ & $750 \mathrm{~mL} /$ day & $37-75 \mu \mathrm{g} /$ day & $50 \%$ & $150 \mu \mathrm{g} / \mathrm{day}$ & $\mathrm{INL} 98$ \\
$\begin{array}{c}\text { The Netherlands } \\
\text { Denmark, Iceland } \\
\text { and Sweden }\end{array}$ & $60 \mu \mathrm{g} / \mathrm{L}$ & $800 \mathrm{~mL} /$ day & $48 \mu \mathrm{g} /$ day & $50 \%$ & $100 \mu \mathrm{g}$ DFE/day & $\mathrm{INL} 98$ \\
$\begin{array}{c}\text { United Kingdom } \\
\text { United States } \\
\text { and Canada }\end{array}$ & $-85 \mu \mathrm{g} / \mathrm{L}$ & $750 \mathrm{~mL} /$ day & $\mathrm{nc}$ & $50 \%$ & $100 \mu \mathrm{g} / \mathrm{day}$ & $\mathrm{INL} 98$ \\
\hline
\end{tabular}

ANR: average nutrient requirement; DFE: dietary folate equivalents; INL: individual nutrient level; nc: not calculated in report; ${ }^{1}$ NIVs are calculated as an additional requirement that is added to the NIV for NPNL women; ${ }^{2}$ values may be rounded; ${ }^{3}$ proposed values to be approved August 2013 [86].

The factorial approach used to determine NIVs for lactating women assumes that milk folate content can be used as a proxy for maternal folate adequacy. However, evidence indicates that adequate milk folate content is maintained during folate depletion states [5]. While there is some evidence to suggest that blood folate status of lactating women decreases as lactation progresses [153,154], further longitudinal studies are needed to confirm this observation. It has been suggested that folate status of the lactating mother in these study populations often declines merely due to the discontinuation of prenatal folic acid supplements [154]. A number of studies have been carried out on maintenance of blood folate status during lactation [76,152,155-157]; however, these studies have also been conducted in groups of women who had consumed high-dose folic acid supplements throughout pregnancy.

Lastly, NIVs for lactation do not account for the influence of birth spacing on maternal nutritional status. Short intervals between pregnancies have been associated with increased risk of preterm birth, 
low birth-weight, and small-for-gestational-age babies [158]. Although the cause of these poor reproductive outcomes among women with short birth spacing has been debated, one plausible hypothesis is that women with closely spaced births have insufficient time to restore the folate reserves needed to support optimal fetal growth and development in the subsequent pregnancy [159]. Folate supplementation during early and late pregnancy has been shown to reduce the association between short inter-pregnancy spacing and low-birth weight [160]. In populations where supplementation rates during pregnancy are low, it may be of benefit to achieve an intake level that maintains blood folate status during both pregnancy and lactation.

\section{Conclusions}

NIVs set by different countries for folate vary substantially. Among countries, the range of $\mathrm{INL}_{98}$ levels were 160-460 $\mu \mathrm{g}$ /day for NPNL women, 300-750 $\mu \mathrm{g} /$ day for pregnant women, and $260-650 \mu \mathrm{g} /$ day for lactating women. Differences in the indicators selected, the criteria for adequacy, and the type of evidence and assumptions made to set recommendations are all likely to contribute to the variation; however, the lack of transparency in the decisions made ultimately hampers the understanding of the differences [161]. The need to standardize nutrient requirements has also been recognized by the EURopean micronutrient RECommendations Aligned (EURRECA) Network of Excellence in 2007. Although funding for EURRECA ended in 2012, the primary aim of the initiative was to provide a harmonized approach to guide the process of deriving micronutrient requirements in the European populations. Activities included the development and dissemination of a framework outlining the ideal process for deriving dietary reference values in a transparent, systematic and scientific way [162]. Despite the WHO/FAO recommendations on establishing a common terminology for NIVs, it was felt for practical purposes that establishing a common European terminology may lead to miscommunication and misinterpretation of NIVs at a national level [162]. EURRECA have also established a list of priority nutrients for review on the basis of: the amount of new evidence available; public health relevance of the nutrient; and variation in current recommendations of different European countries [163]. Folate was ranked in the top ten nutrients prioritized, fulfilling all three criteria in all life-stage groups, except for infancy, for which folate did not meet the criteria of public health relevance. However, despite an ongoing accumulation of evidence linking folate status with health outcomes, undertaking a formal review of folate requirements may prove difficult. A recent systematic review performed to support revision of the NNR folate requirement concluded that there was insufficient quality evidence to question current folate recommendations [164]; regardless, revision of older NIVs, such as those set by the UK (1991), European Union (1993), and the IOM (1998), may be justified. There is a lack of evidence for differences in requirements of folate among countries for NPNL women, and pregnant and lactating women in well-nourished populations; therefore achieving consensus in NIVs supported by a wide evidence base should be a priority.

Although challenging, additional studies in these life-stage populations groups are urgently needed. Most of the evidence supporting folate NIVs has been limited by data from relatively small sample sizes and uncertainties in bioavailability factors. Issues regarding laboratory measurement of food folate and biochemical folate status still exist and will need to be resolved in order to accurately determine dietary intake and provide definitive conclusions on the extent of folate deficiency. Once 
these issues are resolved, further studies are needed to evaluate the metabolic consequences associated with inadequate folate intakes and the reversal of these changes with increased intake levels. Controlled-metabolic studies are not feasible in large samples nor for a period of time long enough to observe a plateau in blood folate response; however it is possible to set NIVs based on observational data if intake data are accurate and captured over a sufficient period of time to ensure the sample days are truly representative of usual intake. For NPNL women, long-term observational studies of dietary folate intake in relation to erythrocyte concentration should not only be adequately powered to provide a precise estimate of the average requirement, but also to determine the variation in requirements. Given the importance of folate in prevention of NTDs during preconception, a higher erythrocyte folate status may serve as a better indicator of adequacy in NPNL women than erythrocyte folate status required to prevent megaloblastic anemia.

For pregnant women, there is reasonably good evidence that an additional $100 \mu \mathrm{g}$ folic acid/day above the requirement for NPNL women is adequate to prevent against a decline in blood folate in a population with adequate intakes and a low prevalence of megaloblastic anemia. Differences among countries NIVs for pregnant women are largely due to differences in NIVs of NPNL women. Studies of folate requirements in pregnant women designed to maintain optimal folate status will be confounded by the use of high-dose supplements in the range of 400-1000 $\mu \mathrm{g}$ folic acid during preconception and early pregnancy $[76,129,152,165]$. It is important to determine future requirements based on an optimal erythrocyte folate level rather than maintenance of status in such populations, and to consider the effect of high-dose supplements on subsequent folate requirements throughout pregnancy. Similarly, this confounding effect should also be considered when evaluating folate status data during lactation. The current approach for deriving folate requirements during lactation with use of breastmilk folate content as a proxy for maternal adequacy may be inappropriate. Further research designed to evaluate the relationship between folate intake and blood folate status or other indicators during lactation among previously un-supplemented women are required.

\section{Acknowledgments}

We thank Rosalind Gibson for her helpful discussions on the international harmonization efforts, which enhanced our understanding of approaches and methods used for the development of NIVs.

\section{Conflicts of Interest}

The authors declare no conflict of interest.

\section{References}

1. Stover, P.J. Folate Biochemical Pathways and Their Regulation. In Folate in Health and Disease, 2nd ed.; Bailey, L.B., Ed.; CRC Press: Boca Raton, FL, USA, 2010; pp. 49-74.

2. Lamers, Y. Folate recommendations for pregnancy, lactation, and infancy. Ann. Nutr. Metab. 2011, 59, 32-37. 
3. Tamura, T.; Picciano, M.F.; McGuire, M.K. Folate in Pregnancy and Lactation. In Folate in Health and Disease, 2nd ed.; Bailey, L.B., Ed.; CRC Press: Boca Raton, FL, USA, 2010; pp. 111-131.

4. Hansen, H.; Rybo, G. Folic acid dosage in profylactic treatment during pregnancy. Acta Obstet. Gynecol. Scand. 1967, 46, 107-112.

5. Metz, J. Folate deficiency conditioned by lactation. Am. J. Clin. Nutr. 1970, 23, 843-847.

6. Willoughby, M.L.; Jewell, F.J. Folate status throughout pregnancy and in postpartum period. Br. J. Med. 1968, 4, 356-360.

7. Committee on Maternal Nutrition; Food and Nutrition Board; National Research Council. Maternal Nutrition and the Course of Pregnancy; National Academy of Sciences: Washington, DC, USA, 1970.

8. Berry, R.J.; Mulinare, J.; Hamner, H.C. Neural Tube Defect Risk Reduction-A Global Health Perspective. In Folate in Health and Disease, 2nd ed.; Bailey, L.B., Ed.; CRC Press: Boca Raton, FL, USA, 2010; pp. 179-204.

9. Christian, P.; Murray-Kolb, L.E.; Khatry, S.K.; Katz, J.; Schaefer, B.A.; Cole, P.M.; Leclerg, S.C.; Tielsch, J.M. Prenatal micronutrient supplementation and intellectual and motor function in early school-aged children in Nepal. JAMA 2010, 304, 2716-2723.

10. Roth, C.; Magnus, P.; Schjøberg, S.; Stotenberg, C.; Surén, P.; McKeague, I.W.; Davey Smith, G.; Reichborn-Kjennerud, T.; Susser, E. Folic acid supplements in pregnancy and severe language delay in children. JAMA 2011, 306, 1566-1573.

11. Schmidt, R.J.; Tancredi, D.J.; Ozonoff, S.; Hansen, R.L.; Hartiala, J.; Allayee, H.; Schmidt, L.C.; Tassone, F.; Hertz-Picciotto, I. Maternal periconceptional folic acid intake and risk of autism spectrum disorders and developmental delay in the CHARGE (CHildhood Autism Risks from Genetics and Environment) case-control study. Am. J. Clin. Nutr. 2012, 96, 80-89.

12. Veena, S.R.; Krishnaveni, G.V.; Srinivasan, K.; Wills, A.K.; Muthayya, S.; Kurpad, A.V.; Yajnik, C.S.; Fall, C.H.D. Higher maternal plasma folate but not vitamin B-12 concentrations during pregnancy are associated with better cognitive function scores in 9- to 10-year old choldren in South India. J. Nutr. 2010, 140, 1014-1022.

13. King, J.C.; Garza, C. Harmonization of nutrient intake values. Food Nutr. Bull. 2007, 28, S3-S12.

14. King, J.C.; Vorster, H.H.; Tome, D.G. Nutrient Intake Values (NIVs): A recommended terminology and framework for the derivation of values. Food Nutr. Bull. 2007, 28, S16-S26.

15. Murphy, S.P.; Vorster, H.H. Methods for using Nutrient Intake Values (NIVs) to assess or plan nutrient intakes. Food Nutr. Bull. 2007, 28, S51-S60.

16. National Health and Medical Research Council. Nutrient Reference Values for Australia and New Zealand; NHMRC: Canberra, Australia, 2006.

17. German Nutrition Society; Austrian Nutrition Society; Swiss Society for Nutrition Research; Swiss Nutrition Association. Referenzwerte für die Nährstoffzufuhr, 1st ed.; Umschau/Braus: Frankfurt am Main, Germany, 2000.

18. Superior Health Council. Voedingsaanbevelingen voor België; Superior Health Council: Brussels, Belgium, 2009. 
19. Agência Nacional de Vigilância Sanitária. Resolução RDC n. 269, de 22 de Setembro de 2005. Regulamento Técnico Sobre a Ingestão Diária Recomendada (IDR) de Proteína, Vitaminas E Minerais. In Diário Oficial da República Federativa do Brasil; Ministério da Saúde: Brasília, Brazil, 2005.

20. Ministry of Health. Наредба № 23 от 19 Юли 2005 г. за Физиологичните Норми за Хранене на Населението; Ministry of Health: Sofia, Bulgaria, 2005.

21. Torun, B.; Menchu, M.T.; Elias, L.G. Recomendaciones Dietéticas Diarias del INCAP; Instituto de Nutricíon de Centro América y Panamá (INCAP): Guatemala City, Guatemala, 1994.

22. Chinese Nutrition Society. Chinese Dietary Reference Intakes (in Chinese); China Light Industry Press: Beijing, China, 2010.

23. Instituto Colombiano de Bienestar Familiar. Recomendaciones de Consumo Diario de Calorías y Nutrientes para la Población Colombiana; Instituto Colombiano Bienestar Familiar: Bogotá, Colombia, 1988.

24. Ministry of Health and Social Welfare. Pravilnik o Hrani za Posebne Prehrambene Potrebe. In Narodne Novine; Narodne Novine d.d.: Zagreb, Croatia, 2004.

25. Hernández-Triana, M.; Porrata, C.; Jiménez, S.; Rodriguez, A.; Carrillo, O.; García, A.; Valdés, L.; Esquivel, M. Dietary reference intakes for the cuban population, 2008. MEDICC Rev. 2009, 11, 9-16.

26. Nordic Council of Ministers. Nordic Nutrition Recommendations 2004. Integrating Nutrition and Physical Activity, 4th ed.; Nordic Council of Ministers: Copenhagen, Denmark, 2005.

27. Tervise Arengu Insitituut; Eesti Toitumisteaduse Selts (Estonian Nutrition Society). Eesti Toitumis-ja Toidusoovitused; Eesti Toitumisteaduse Selts (Estonian Nutrition Society): Tallinn, Estonia, 2006.

28. Commission of the European Communities. Nutrient and Energy Intakes for the European Community. In Reports of the Scientific Committee for Food (Thirty-First Series); Commission of the European Communities, Directorate-General Telecommunications, Information Industries and Innovation: Luxembourg, Luxembourg, 1993.

29. National Nutrition Council. Soumalaiset Ravitsemussuositukset Ravinto ja Liikunta Tasapainoon; Edita Publishing Oy: Helsinki, Finland, 2005.

30. Martin, A. Apports Nutritionnels Conseillés pour la Population Française, 3rd ed.; Tec et Doc: Paris, France, 2000.

31. Supreme Scientific Health Council; Ministry of Health and Welfare. Dietary guidelines for adults in Greece. Arch. Hell. Med. 1999, 16, 516-524.

32. Rodler, I. Új Tápanyagtáblázat; Medicina Könyvkiadó: Budapest, Hungary, 2005.

33. Indian Council of Medical Research; National Institute of Nutrition. Nutrient Requirements and Recommended Dietary Allowances for Indians: A Report of the Expert Group of the Indian Council of Medical Research; Indian Council of Medical Research: New Dehli, India, 2010.

34. Food Safety Authority of Ireland. Recommended Dietary Allowances for Ireland 1999; Food Safety Authority of Ireland: Dublin, Ireland, 1999.

35. Societá Italiana di Nutrizione Umana. LARN_Livelli di Assunzione di Riferimento di Nutrienti ed Energia per la Popolazione Italiana; Societá Italiana di Nutrizione Umana: Milan, Italy, 2012. 
36. The Scientific Committee of "Dietary Reference Intakes for Japanese-Recommended Dietary Allowance". Dietary Reference Intakes for Japanese; Ministry of Health, Labour and Welfare: Tokyo, Japan, 2005.

37. Veselības Ministrijas (Ministry of Health). Ieteicamās Energijas un Uzturvielu devas Latvajas Iedzīvotājiem; Ministry of Health: Riga, Latvia, 2008.

38. Svelkatos Apsaugos Ministerija (Ministry of Health). Rekomenduojamos Paros Maistiniu Medžiagu ir Energijos Normos; Valstybès žinios: Vilnius, Lithuania, 1999.

39. Bourges, H.; Casanueva, E.; Rosado, J.L. Recomendaciones de Ingestión de Nutrimentos Para la Población Mexicana: Bases Fisiológicas: Vitaminas y Nutrimentos Inorgánicos; Editorial Médica Panamericana: Mexico City, Mexico, 2005.

40. Helsedirektoratet. Norske Anbefalinger for Erncering og Fysisk Aktivitet; Helsedirektoratet: Oslo, Norway, 2005.

41. Bułhak-Jachymczyk, B.; Chabros, E. Normy Żywienia Człowieka; Wydawnictwo Lekarskie PZWL: Warsaw, Poland, 2008.

42. Ministry of Health; Republic Institute of Health Protection. Nutrient Recommendations as Addition to Guidelines for Healthy Nutrition of the Population in Republic of Macedonia; Ministry of Health: Skopje, Republic of Macedonia, 2001.

43. Stojisavljević, D.; Danojević, D.; Bojanić, J.; Jandrić, L. Vodič za Pravilnu Ishranu za Zdravstvene Profesionalce; Institut za Zaštitu Republike Srpske: Banja Luka, Bosnia and Herzegovina, 2004.

44. Тутельян, В.А.; Батурин, А.К.; Гаппаров, М.Г.; Каганов, Б.С.; Конь, И.Я.; Мазо, В.К.; Баева, В.С.; Бессонов, В.В.; Васильев, А.В.; Волкова, Л.Ю.; et al. MP-08 2.3.1.2432-Hopмы Физиологических Потребностей в Энергии и Пищевых Веществах для Различных Групп Населения Российской Федерации; Cheif Medical Officer of Russia: Moscow, Russia, 2008.

45. Ministerstva Zdravotníctva Slovenskej Republiky. Odporúčané Výživové Dávky pre Obyvatel'stvo v Slovenskej Republike; Ministerstva Zdravotníctva Slovenskej Republiky: Bratislava, Slovakia, 1997.

46. Debenjak, P.; Arbeitsgruppe Referenzwerte für die Nährstoffzufuhf. Referenčne Vrednosti za vnos Hranil, 1st ed.; Ministrstvo za Zdrave: Ljubljana, Slovenia, 2004.

47. The Korean Nutrition Society. Dietary Reference Intakes for Koreans (in Korea), 1st ed; The Korean Nutrition Society: Seoul, Korea, 2010.

48. Tee, E.-S.; Florentino, R.F. Recommended Dietary Allowances: Harmonization in Southeast Asia; International Life Sciences Institute: Singapore, Singapore, 2005.

49. Federación Española de Sociedades de Nutrición Alimentación y Dietética (FESNAD). Ingestas Dietéticas de Referencia (IDR) para la Población Española; Ediciones Universidad de Navarra, S.A. (EUNSA): Navarra, Spain, 2010.

50. Health Council of The Netherlands. Voedingsnormen: Vitamine B6, Foliumzuur en Vitamine B12; Health Council of The Netherlands: The Hague, The Netherlands, 2003.

51. Department of Health. Dietary Reference Values for Food Energy and Nutrients for the United Kingdom: Report of the Panel on Dietary Reference Values of the Committee on Medical Aspects of Food Policy. In Report on Health and Social Subjects; HMSO: London, UK, 1991; Volume 41, pp. 109-112. 
52. Institute of Medicine. Dietary Reference Intakes for Thiamin, Riboflavin, Niacin, Vitamin B6, Folate, Vitamin B12, Pantothenic Acid, Biotin, and Choline; National Academies Press: Washington, DC, USA, 1998.

53. World Health Organization; Food and Agriculture Organization. Vitamin and Mineral Requirements in Human Nutrition. In proceedings of the Joint FAO/WHO Expert Consultation, Bangkok, Thailand, 21-30 September 1998; World Health Organization: Geneva, Switzerland, 2004.

54. Selhub, J. Homocysteine metabolism. Annu. Rev. Nutr. 1999, 19, 217-246.

55. Clarke, R.; Halsey, J.; Lewington, S.; Lonn, E.; Armitage, J.; Manson, J.E.; Bønaa, K.H.; Spence, J.D.; Nygård, O.; Jamison, R.; et al. Effects of lowering homocysteine levels with $\mathrm{B}$ vitamins on cardiovascular disease, cancer, and cause-specific mortality. Arch. Intern. Med. 2010, 170, 1622-1631.

56. Wu, A.; Chanarin, I.; Slavin, G.; Levi, A.J. Folate deficiency in the alcoholic - Its relationship to clinical and haematological abnormalites, liver disease and folate stores. Br. J. Haematol. 1975, 29, 469-478.

57. Eichner, E.R.; Pierce, I.; Hillman, R.S. Folate balance in dietary-induced megaloblastic anemia. N. Engl. J. Med. 1971, 284, 933-938.

58. Herbert, V. Experimental folate deficiency in man. Trans. Assoc. Am. Physicians 1962, 75, 307-320.

59. Herbert, V. Making sense of laboratory tests of folate status: Folate requirements to sustain normality. Am. J. Hematol. 1987, 26, 199-207.

60. Hoffbrand, A.V.; Newcombe, B.F.; Mollin, D.L. Method of assay of red cell folate activity and the value of the assay as a test for folate deficiency. J. Clin. Pathol. 1966, 19, 17-28.

61. Varadi, S.; Abbott, D.; Elwis, A. Correlation of peripheral white cell and bone marrow changes with folate levels in pregnancy and their clinical significance. J. Clin. Pathol. 1966, 19, 33-36.

62. Blount, B.C.; Mack, M.M.; Wehr, C.M.; MacGregor, J.T.; Hiatt, R.A.; Wang, G.; Wickramasinghe, S.N.; Everson, R.B.; Ames, B.N. Folate deficiency causes uracil misincorporation into human DNA and chromosome breakage: Implications for cancer and neuronal damage. Proc. Natl. Acad. Sci. USA 1997, 94, 3290-3295.

63. Gunter, E.W.; Bowman, B.A.; Caudill, S.P.; Twite, D.B.; Adams, M.J.; Sampson, E.J. Results of an international round robin for serum and whole-blood folate. Clin. Chem. 1996, 42, 1689-1694.

64. Pfeiffer, C.M.; Fazili, Z.; Zhang, M. Folate Analytical Methodology. In Folate in Health and Disease; Bailey, L.B., Ed.; CRC Press: Boca Raton, FL, USA, 2010; pp. 517-574.

65. Pfeiffer, C.M.; Zhang, M.; Lacher, D.A.; Molloy, A.M.; Tamura, T.; Yetley, E.A.; Picciano, M.F.; Johnson, C. Comparison of serum and red blood cell folate microbiologic assays for national population surveys. J. Nutr. 2011, 141, 1402-1409.

66. Fazili, Z.; Pfeiffer, C.M. Accounting for an isobaric interference allows correct determination of folate vitamers in serum by isotype dilution-liquid chromatography-tandem MS. J. Nutr. 2013, 143, 108-113.

67. Nelson, B.C.; Pfeiffer, C.M.; Margiolis, S.A.; Nelson, C.P. Affinity extraction combined with stable isotope dilution LC/MS for the determination of 5-methyltetrahydrofolate in human plasma. Anal. Biochem. 2003, 313, 117-127. 
68. Pfeiffer, C.M.; Fazili, Z.; McCoy, L.; Zhang, M.; Gunter, E.W. Determination of folate vitamers in human serum by stable-isotope-dilution tandem mass spectrometry and comparison with radioassay and microbiologic assay. Clin. Chem. 2004, 50, 423-432.

69. Fazili, Z.; Pfeiffer, C.M. Measurement of folates in serum and conventionally prepared whole blood lysates: Application of an automated 96-well plate isotope-dilution tandem mass spectrometry method. Clin. Chem. 2004, 50, 2378-2381.

70. Fazili, Z.; Pfeiffer, C.M.; Zhang, M.; Jain, R. Erythrocyte folate extraction and quantitative determination by liquid chromatography-tandem mass spectroemetry: Comparision of results with microbiologic assay. Clin. Chem. 2005, 51, 2318-2325.

71. Fazili, Z.; Pfeiffer, C.M.; Zhang, M.; Jain, R.; Koontz, D. Influence of 5,10-methylenetetrahydrofolate reductase polymorphism on whole-blood folate concentration measured by LC-MS/MS, microbiologic assay, and bio-rad radioassay. Clin. Chem. 2008, 54, 197-201.

72. Ohrvik, V.E.; Witthoft, C.M. Human folate bioavailability. Nutrients 2011, 3, 475-490.

73. Hannon-Fletcher, M.P.; Armstrong, N.C.; Scott, J.M.; Pentieva, K.; Bradbury, I.; Ward, M.; Strain, J.J.; Dunn, A.A.; Molloy, A.M.; Kerr, M.A.; et al. Determining bioavailability of food folates in a controlled intervention study. Am. J. Clin. Nutr. 2004, 80, 911-918.

74. Brouwer, I.A.; van Dusseldorp, M.; West, C.; Meyboom, S.; Thomas, C.M.G.; Duran, M.; van het Hof, K.H.; Eskes, T.K.A.B.; Hautvast, G.A.J.; Steegers-Theunissen, R.P.M. Dietary folate from vegetables and citrus fruit decreases plasma homocysteine concentrations in humans in a dietary controlled trial. J. Nutr. 1999, 129, 1135-1139.

75. Green, T.; Liu, Y.; Dadgar, S.; Li, W.; Böhni, R.; Kitts, D.D. Wheat rolls fortified with microencapsulated L-5-methyltetrahydrofolic acid or equimolar folic acid increase blood folate concentrations to a similar extent in healthy men and women. J. Nutr. 2013, 143, 867-871.

76. Houghton, L.A.; Sherwood, K.L.; Pawlosky, R.; Ito, S.; O’Connor, D.L. [6S]-5Methyltetrahydrofolate is at least as effective as folic acid in preventing a decline in blood folate concentrations during lactation. Am. J. Clin. Nutr. 2006, 83, 842-850.

77. Pentieva, K.; McNulty, H.; Reichert, R.; Ward, M.; Strain, J.J.; McKillop, D.J.; McPartlin, J.M.; Connolly, E.; Molloy, A.; Kramer, K.; et al. The short-term bioavailabilities of [6S]-5methyltetrahydrofolate and folic acd are equivalent in men. J. Nutr. 2004, 134, 580-585.

78. Christensen, K.E.; Rozen, R. Genetic Variation. Effect on Folate Metabolism and Health. In Folate in Health and Disease, 2nd ed.; Bailey, L.B., Ed.; CRC Press: Boca Raton, FL, USA, 2010; pp. 75-110.

79. Guéant-Rodriguez, R.-M.; Guéant, J.-L.; Debard, R.; Thirion, S.; Hong, L.X.; Bronowicki, J.-P.; Namour, F.; Chabi, N.W.; Sanni, A.; Anello, G.; et al. Prevalence of methylenetetrahydrofolate reductase $677 \mathrm{~T}$ and $1298 \mathrm{C}$ alleles and folate status: A comparative study in Mexican, West African, and European populations. Am. J. Clin. Nutr. 2006, 83, 701-707.

80. Wilcken, B.; Bamforth, F.; Li, Z.; Zhu, H.; Ritvanen, A.; Redlund, M.; Stoll, C.; Alembik, Y.; Dott, B.; Czeizel, A.E.; et al. Geographical and ethnic variation of the $677 \mathrm{C}>\mathrm{T}$ allele of 5,10 methylenetetrahydrofolate reductase (MTHFR): Findings from over 7000 newborns from 16 areas world wide. J. Med. Genet. 2003, 40, 687-693. 
81. De Bree, A.; Verschuren, W.M.M.; Bjørke-Monsen, A.L.; van der Put, N.M.J.; Heil, S.G.; Trijbels, F.J.M.; Blom, H.J. Effect of the methylenetetrahydrofolate reductased $677 \mathrm{C} \rightarrow \mathrm{T}$ mutation on the relations among folate intake and plasma folate and homocysteine concentrations in a general population sample. Am. J. Clin. Nutr. 2003, 77, 687-693.

82. Nagele, P.; Meissner, K.; Francis, A.; Födinger, M.; Saccone, N.L. Genetic and environmental determinants of plasma total homocysteine levels: Impact of population-wide folate fortification. Pharmacogenet. Genomics 2011, 21, 426-431.

83. Yang, Q.-H.; Botto, L.D.; Gallagher, M.; Friedman, J.M.; Sanders, C.L.; Koontz, D.; Nikolova, S.; Erickson, J.D.; Steinberg, K. Prevalence and effects of gene-gene and gene-nutrient interactions on serum folate and serum total homocysteine concentrations in the United States: Findings from the third National Health and Nutrition Examination Survey DNA Bank. Am. J. Clin. Nutr. 2008, $88,232-246$.

84. Gibney, M.J.; Gibney, E.R. Diet, genes and disease: Implications for nutrition policy. Proc. Nutr. Soc. 2004, 63, 491-500.

85. Robataille, J.; Hamner, H.C.; Cogswell, M.E.; Yang, Q. Doe the MTHFR 677C $\rightarrow$ T variant affect the Recommended Dietary Allowance for folate in the US population? Am. J. Clin. Nutr. 2009, 89, 1269-1273.

86. German Nutrition Society; Austrian Nutrition Society; Swiss Society for Nutrition Research; Swiss Nutrition Association. Referenzwerte für die Nährstoffzufuhr: Folat, 5th ed.; Neuer Umschau Buchverlag: Neustadt an der Weinstraße, Germany, 2013.

87. Food and Nutrition Board. Recommended Dietary Allowances, 10th ed.; National Academy of Sciences: Washington, DC, USA, 1989.

88. Food and Nutrition Board. Recommended Dietary Allowances, 9th ed.; National Academy of Sciences: Washington, DC, USA, 1980.

89. Food and Nutrition Board. Recommended Dietary Allowances, 8th ed.; National Academy of Sciences: Washington, DC, USA, 1974.

90. Food and Nutrition Board. Recommended Dietary Allowances, 7th ed.; National Academy of Sciences: Washington, DC, USA, 1968.

91. Food and Agriculture Organization. Requirements of Vitamin A, Iron, Folate and Vitamin B12. Report of a Joint FAO/WHO Expert Consultation. In FAO Food and Nutrition Series No. 23; Food and Agriculture Organization of the United Nations: Rome, Italy, 1988.

92. European Surveillance of Congenital Anomalies (EUROCAT). Special Report: Prevention of Neural Tube Defects by Periconceptional Folic Acid Supplementation in Europe. Part IIa: Country Specific Chapters (Austria to Ireland); European Surveillance of Congenital Anomalies: Newtonabbey, Ireland, 2009.

93. European Surveillance of Congenital Anomalies (EUROCAT). Special Report: Prevention of Neural Tube Defects by Periconceptional Folic Acid Supplementation in Europe. Part IIb: Country Specific Chapters (Italy to UK); European Surveillance of Congenital Anomalies: Newtonabbey, Ireland, 2009.

94. Herbert, V. Minimal daily adult folate requirement. Arch. Intern. Med. 1962, 110, 649-652.

95. Sauberlich, H.E.; Kretsch, M.J.; Skala, J.H.; Johnson, H.L.; Taylor, P.C. Folate requirement and metabolism in nonpregnant women. Am. J. Clin. Nutr. 1987, 46, 1016-1028. 
96. O’Keefe, C.A.; Bailey, L.B.; Thomas, E.A.; Hofler, S.A.; Davis, B.A.; Cerda, J.J.; Gregory, J.F. Controlled dietary folate affects folate status in nonpregnant women. J. Nutr. 1995, 125, 2717-2725.

97. Milne, D.B.; Johnson, L.K.; Mahalko, J.R.; Sandstead, H.H. Folate status of adult males living in a metabolic unit: Possible relationships with iron nutriture. Am. J. Clin. Nutr. 1983, 37, 768-773.

98. Jacob, R.A.; Wu, M.M.; Henning, S.M.; Swendseid, M.E. Homocysteine increases as folate decreases in plasma of healthy men during short-term dietary folate and methyl group restriction. J. Nutr. 1994, 124, 1072-1080.

99. Houghton, L.A.; Gray, A.R.; Rose, M.C.; Miller, J.C.; Hursthouse, N.A.; Gregory, J.F. Long-term effect of low-dose folic acid intake: Potential effect of mandatory fortification on the prevention of neural tube defects. Am. J. Clin. Nutr. 2011, 94, 136-141.

100. Metz, J. A high prevalence of biochemical evidence of vitamin B12 or folate deficiency does not translate into a comparable prevalance of anemia. Food Nutr. Bull. 2008, 29, S74-S85.

101. Shaw, G.M.; Schaffer, D.; Velie, E.M.; Morland, K.; Harris, J.A. Periconceptional vitamin use, dietary folate, and the occurance of neural tube defects. Epidemiology 1995, 6, 219-226.

102. Werler, M.M.; Shapiro, S.; Mitchell, A.A. Periconceptional folic acid exposure and risk of occurrent neural tube defects. JAMA 1993, 269, 1257-1261.

103. Crider, K.S.; Bailey, L.B.; Berry, R.J. Folic acid fortification-Its history, effect, concerns, and future directions. Nutrients 2011, 3, 370-384.

104. McLennan, W.; Podger, A. National Nutrition Survey. Nutrient Intakes and Physical Measurements Australia 1995; Australian Bureau of Statistics: Canberra, Australia, 1998.

105. Health Canada; Statistics Canada. Canadian Community Health Survey Cycle 2.2, Nutrition (2004). Nutrient Intakes from Food. Provincial, Regional and National Summary Data Tables, Volume 2; Health Canada: Ottawa, Canada, 2008.

106. Andersen, N.L.; Fagt, S.; Groth, M.V.; Harktopp, H.B.; Moller, A.; Ovesen, L.; Warming, D.L. Danskernes Kostvaner 1995: Hovedresultater; Levnedsmiddelstyrelsen: Saborg, Denmark, 1996.

107. Alfthan, G.; Laurinen, M.S.; Valsta, L.M.; Pastinen, T.; Aro, A. Folate intake, plasma folate and homocysteine status in a ransom Finnish population. Eur. J. Clin. Nutr. 2003, 57, 81-88.

108. Paturi, M.; Tapanainen, H.; Reinivuo, H.; Pietinen, P. Finravinto 2007-Tutkimus. The National FINDIET 2007 Survey; National Public Health Insititute: Helsinki, Finland, 2008.

109. Beitz, R.; Mensink, G.B.M.; Fisher, B.; Thamm, M. Vitamins-Dietary intake and intake from dietary supplements in Germany. Eur. J. Clin. Nutr. 2002, 56, 539-545.

110. Max Rubner-Institut; Bundesforschungsinstitut für Ernährung und Lebensmittel. Ergebnisbericht, Teil 2. Nationale Verzhrsstudie II. Die Bundesweite Befragung zur Ernährung von Jugendlichen und Erwachsenen; Max Rubner-Institut: Karlsruhe, Germany, 2008.

111. O’Brien, M.M.; Kiely, M.; Harrington, K.E.; Robson, P.J.; Strain, J.J.; Flynn, A. The North/South Ireland Food Consumption Survey: Vitamin intakes in 18-64-year-old adults. Public Health Nutr. 2001, 4, 1069-1079.

112. Russell, D.G.; Parnell, W.; Wilson, N.C.; The Principle Investigators of the 1997 National Nutrition Survey. NZ Food: NZ People. Key Results of the 1997 National Nutrition Survey; Ministry of Health: Wellington, New Zealand, 1999. 
113. Serra Majem, L.; Ribas Barba, L.; Garcia Closas, R.; Ballart, J.F.; Guayta Escolier, R. Libre Blanc: Avaluació de L'estat Nutricional de la Població Catalana (1992-93): Avaluació dels Hábits Alimentaris, el Consum D'aliments, Energia $i$ Nutrients $i$ de L'estat Nutricional Mitjançant Indicadors Bioquímics i Antropomètrics; Generalidad de Catalunya: Barcelona, Spain, 1996.

114. Becker, W.; Pearson, M. Riksmaten 1997-98. Kostvanor och Näringsintag i Sverige. Metodoch Resultatanalys; Livsmedelsverket: Uppsala, Sweden, 2002.

115. Bausch-Goldbohm, R.A.; Hulshof, K.F.A.M.; Brants, H.A.M.; van den Berg, H.; Bouman, M. De Inneming van Foliumzuur Door Verschillende Bevolkingsgroepen in Nederland voor en na Verrijking van Bepaalde Voedingsmiddelen. Voedselconsumptiepeiling 1992; TNO Voeding: Zeist, The Netherlands, 1995.

116. De Bree, A.; Verschuren, W.M.M.; Blom, H.J.; Kromhout, D. Association between B vitamin intake and plasma homocysteine concentration in the general Dutch population aged 20-65 year. Am. J. Clin. Nutr. 2001, 73, 1027-1033.

117. Hulshof, K.F.A.M.; Ocké, M.C.; van Rossum, C.T.M.; Buurma-Rethans, E.J.M.; Brants, H.A.M.; Drijvers, J.J.M.M.; ter Doest, D. Resultaten van de Voedselconsumptiepeiling 2003; Rijksinstituut voor Volksgezondheid en Milieu: Bilthoven, The Netherlands, 2004.

118. National Institure for Public Health and the Environmen; van Rossum, C.T.M.; Fransen, H.P.; Verkaik-Kloosterman, J.; Buurma-Rethans, E.J.M.; Ocké, M.C. Dutch National Food Consumption Survey 2007-2010. Diet of Children and Adults Aged 7 to 69 years; Colophon: Bilthoven, The Netherlands, 2011.

119. Gregory, J.; Foster, K.; Tyler, H.; Wiseman, M. The Dietary and Nutritional Survey of British Adults; HMSO: London, UK, 1990.

120. Henderson, L.; Irving, K.; Gregory, J.; Bates, C.J.; Prentice, A.; Perks, J.; Swan, G.; Farron, M. The National Diet \& Nutrition Survey: Adults Aged 19 to 64 Years. Vitamin and Mineral Intake and Urinary Analytes; HMSO: London, UK, 2003.

121. Bates, B.; Lennox, A.; Bates, C.; Swan, G. National Diet and Nutrition Survey: Headline Results from Years 1 and Years 2 (Combined) of the Rolling Programme 2008-9-2009-10; Department of Health: London, UK, 2011.

122. Dietrich, M.; Brown, C.J.P.; Block, G. The effect of folate fortification of cereal-grain products on blood folate status, dietary folate intake, and dietary folate sources among adult non-supplement users in the United States. J. Am. Coll. Nutr. 2005, 4, 266-274.

123. Bailey, R.L.; Dodd, K.W.; Gahche, J.J.; Dwyer, J.T.; McDowell, M.A.; Yetley, E.A.; Sempos, C.A.; Burt, V.L.; Radimer, K.L.; Picciano, M.F. Total folate and folic acid intake from foods and dietary supplements in the United States: 2003-2006. Am. J. Clin. Nutr. 2010, 91, 231-237.

124. Bailey, L.B. Folate Requirements and Dietary Recommendations. In Folate in Health and Disease; Bailey, L.B., Ed.; Marcel Dekker Inc.: New York, NY, USA, 1995.

125. De Bree, A.; van Dusseldorp, M.; Brouwer, I.A.; van het Hof, K.H.; Steegers-Theunissen, R.P.M. Folate intake in Europe: Recommended, actual and desired intake. Eur. J. Clin. Nutr. 1997, 51, 643-660.

126. Chanarin, I.; Rothman, D.; Ward, A.; Perry, J. Folate status and requirement in pregnancy. Br. Med. J. 1968, 2, 390-394. 
127. Willoughby, M.L. An investigation of folic acid requirements in pregnancy. II. Br. J. Haematol. 1967, 13, 503-509.

128. Willoughby, M.L.; Jewell, F.J. Investigation of folic acid requirements in pregnancy. Br. Med. J. 1966, 2, 1568-1571.

129. Caudill, M.A.; Cruz, A.C.; Gregory, J.F.; Hutson, A.D.; Bailey, L.B. Folate status response to controlled folate intake in pregnant women. J. Nutr. 1997, 127, 2363-2370.

130. Chanarin, I.; Rothman, D.; Perry, J.; Stratfull, D. Normal dietary folate, iron, and protein intake, with particular reference to pregnancy. Br. J. Med. 1968, 2, 394-397.

131. Moscovitch, L.F.; Cooper, B.A. Folate content of diets in pregnancy: Comparison of diets collected at home and diets prepared from dietary records. Am. J. Clin. Nutr. 1973, 26, 707-714.

132. Iyengar, L. Folic acid requirements of Indian pregnant women. Am. J. Obstet. Gynecol. 1971, 111, 13-16.

133. McPartlin, J.; Halligan, A.; Scott, J.M.; Darling, M.; Weir, D.G. Accelerated folate breakdown in pregnancy. Lancet 1993, 341, 148-149.

134. Caudill, M.A.; Gregory, J.F.; Hutson, A.D.; Bailey, L.B. Folate catabolism in pregnant and nonpregnant women with controlled folate intakes. J. Nutr. 1998, 128, 204-208.

135. Bakker, R.; Timmermans, S.; Steegers, E.A.P.; Hofman, A.; Jaddoe, V.W.V. Folic acid supplements modify the adverse effects of maternal smoking on fetal growth and neonatal complications. J. Nutr. 2011, 141, 2172-2179.

136. Bergen, N.E.; Jaddoe, V.W.V.; Timmermans, S.; Hofman, A.; Lindemans, J.; Russcher, H.; Raat, H.; Steegers-Theunissen, R.P.M.; Steegers, E.A.P. Homocysteine and folate concentrations in early pregnancy and the risk of adverse pregnancy outcomes: The Generation R Study. Br. J. Obstet. Gynaecol. 2012, 199, 739-751.

137. Bodnar, L.M.; Himes, K.P.; Venkataramanan, R.; Chen, J.-Y.; Evans, R.W.; Meyer, J.L.; Simhan, H.N. Maternal serum folate species in early pregnancy and risk of preterm birth. Am. J. Clin. Nutr. 2010, 92, 864-871.

138. Relton, C.L.; Pearce, M.S.; Parker, L. The influence of erythrocyte folate and serum vitamin B12 status on birth weight. Br. J. Nutr. 2007, 93, 593-599.

139. Scholl, T.O.; Hediger, M.L.; Schall, J.I.; Khoo, C.S.; Fisher, R.L. Dietary and serum folate: Their influence on the outcome of pregnancy. Am. J. Clin. Nutr. 1996, 63, 520-525.

140. Siega-Riz, A.M.; Savitz, D.A.; Zeisel, S.H.; Thorp, J.M.; Herring, A. Second trimester folate status and preterm birth. Am. J. Obstet. Gynecol. 2004, 191, 1851-1857.

141. Nilsen, R.M.; Vollset, S.E.; Monson, A.L.B.; Ulvik, A.; Haugen, M.; Meltzer, H.M.; Magnus, P.; Ueland, P.M. Infant birth size is not associated with maternal intake and status of folate during the second trimester in Norwegian pregnant women. J. Nutr. 2010, 140, 572-579.

142. Fekete, K.; Berti, C.; Trovato, M.; Lohner, S.; Dullemeijer, C.; Souverein, O.W.; Cetin, I.; Decsi, T. Effect of folate intake on health outcomes in pregnancy: A systematic review and meta-analysis on birth weight, placental weight and length of gestation. Nutr. J. 2012, 11, doi:10.1186/1475-2891-1111-1175.

143. Atkinson, S.; Koletzko, B. Determining life-stage groups and extrapolating Nutrient Intake Values (NIVs). Food Nutr. Bull. 2007, 28, S61-S77. 
144. Ek, J. Plasma, red call, and breast milk folacin concentrations in lactating women. Am. J. Clin. Nutr. 1983, 38, 929-935.

145. Smith, A.M.; Picciano, M.F.; Deering, R.H. Folate intake and blood concentrations of term infants. Am. J. Clin. Nutr. 1985, 41, 590-598.

146. Brown, C.M.; Smith, A.M.; Picciano, M.F. Forms of human milk folacin and variation patterns. J. Pediatr. Gastroenterol. Nutr. 1986, 5, 278-282.

147. O’Connor, D.L.; Tamura, T.; Picciano, M.F. Pteroylpolyglutamates in human milk. Am. J. Clin. Nutr. 1991, 53, 930-934.

148. Lim, H.S.; Mackey, A.D.; Tamura, T.; Wong, S.C.; Picciano, M.F. Measurable human milk folate is increased by treatment with $\alpha$-amylase and protease in addition to folate conjugase. Food Chem. 1998, 63, 401-407.

149. Han, Y.-H.; Yon, M.; Han, H.-S.; Kim, H.-Y.; Tamura, T.; Hyun, T.H. Folate contents in human milk and casein-based and soya-based formulas, and folate status of Korean infants. Br. J. Nutr. 2009, 101, 1769-1774.

150. Houghton, L.A.; Yang, J.; O’Connor, D.L. Unmetabolized folic acid and total folate concentrations in breast milk are unaffacted by low-dose folate supplements. Am. J. Clin. Nutr. 2009, 89, 216-220.

151. Khambalia, A.; Latulippe, M.E.; Campos, C.; Merlos, C.; Villalpando, S.; Picciano, M.F.; O'Connor, D.L. Milk folate secretion is not impaired during iron deficiency in humans. J. Nutr. 2006, 136, 2617-2624.

152. Mackey, A.D.; Picciano, M.F. Maternal folate status during extended lactation and the effect of supplemental folic acid. Am. J. Clin. Nutr. 1999, 69, 285-292.

153. Hure, A.J.; Collins, C.E.; Smith, R. A longitudinal study of maternal folate and vitamin B12 status in pregnancy and postpartum, with the same infant markers at 6 months of age. Matern. Child Health J. 2012, 16, 792-801.

154. O’Connor, D.L.; Green, T.; Picciano, M.F. Maternal folate status and lactation. J. Mammary Gland Biol. Neoplasia 1997, 2, 279-289.

155. Keizer, S.; Gibson, R.S.; O'Connor, D.L. Postpartum folic acid supplementation of adolescents: Impact on maternal folate and zinc status and milk composition. Am. J. Clin. Nutr. 1995, 62, 377-384.

156. Ramlau-Hansen, C.H.; Møller, U.K.; Henriksen, T.B.; Nexø, E.; Møller, J. Folate and vitamin B12 in relation to lactation: A 9-month postpartum follow-up study. Eur. J. Clin. Nutr. 2006, 60, 120-128.

157. Smith, A.M.; Picciano, M.F.; Deering, R.H. Folate supplementation during lactation: Maternal folate status, human milk folate content, and their relationship to infant folate status. J. Pediatr. Gastroenterol. Nutr. 1983, 2, 622-628.

158. Conde-Agudelo, A.; Rosas-Bermudez, A.; Kafury-Goeta, C. Birth spacing and risk of adverse perinatal outcomes: A meta-analysis. JAMA 2006, 295, 1809-1823.

159. Conde-Agudelo, A.; Rosas-Bermudez, A.; Castaño, F.; Norton, M.H. Effects of birth spacing on maternal, perinatal, infant, and child health: A systematic review of causal mechanisms. Stud. Fam. Plan. 2012, 43, 93-114. 
160. Van Eijsden, M.; Smits, L.J.M.; van der Wal, M.F.; Bonsel, G.J. Association between short interpregnancy intervals and term birth weight: The role of folate depletion. Am. J. Clin. Nutr. 2008, $88,147-153$.

161. Hermoso, M.; Tabacchi, G.; Iglesia-Altaba, I.; Bel-Serrat, S.; Moreno-Aznar, L.A.; García-Santos, Y.; García-Luzardo, M.R.; Santana-Salguero, B.; Peña-Quintana, L.; Serra Majem, L.; et al. The nutritional requirements of infants. Towards EU alignemet of reference values: The EURRECA network. Matern. Child Health J. 2010, 6, S55-S83.

162. Van't Veer, P.; Heseker, H.; Grammatikaki, E.; Benetou, V.; Grogoric, M.; Margaritis, I.; Raats, M.M.; Wijnhoven, T. EURRECA/WHO workshop report: Deriving micronutrient recommendations: Updating best practices. Ann. Nutr. Metab. 2013, 62, 63-67.

163. Cavelaars, A.E.J.M.; Doets, E.L.; Dhonukshe-Rutten, R.A.M.; Hermoso, M.; Fairweather-Tait, S.J.; Koletzko, B.; Gurinović, M.; Moreno, L.A.; Cetin, I.; Matthys, C.; et al. Prioritizing micronutrients for the purpose of reviewing their requirements: A protocol developed by EURRECA. Eur. J. Clin. Nutr. 2010, 64, S19-S30.

164. Nordic Council of Ministers. Folate-Nordic Nutrition Recommendations 2012-Draft Chapter for Public Consultation; Nordic Council of Ministers: Copenhagen, Denmark, 2012.

165. Branum, A.M.; Bailey, R.; Singer, B.J. Dietary supplement use and folate status during pregnancy in the United States. J. Nutr. 2013, 143, 486-492.

(C) 2013 by the authors; licensee MDPI, Basel, Switzerland. This article is an open access article distributed under the terms and conditions of the Creative Commons Attribution license (http://creativecommons.org/licenses/by/3.0/). 